\title{
PLANTAS MEDICINAIS: RELACIONANDO CONHECIMENTO POPULAR E CIENTÍFICO NA ATENÇÃO PRIMÁRIA À SAÚDE
}

\author{
MEDICINAL PLANTS: LINKING POPULAR AND SCIENTIFIC KNOWLEDGE IN \\ PRIMARY HEALTH CARE
}

\author{
Rodrigo Noll GONÇALVES'; Jéssica Rodrigues da Silva Noll GONÇALVES²; \\ Marilene da Cruz Magalhães BUFFON³; Raquel Rejane Bonato NEGRELLE ${ }^{4}$
}

\begin{abstract}
1 - Mestre em Saúde Coletiva pelo Programa de Pós-Graduação em Saúde Coletiva UFPR
2 - Mestranda em Saúde Coletiva pelo Programa de Pós-Graduação em Saúde Coletiva UFPR

3 - Professora Doutora do Programa de Pós-Graduação em Saúde Coletiva UFPR

4 - Professora Doutora do Programa de Pós-Graduação em Agronomia - Produção Vegetal UFPR Autor para correspondência: rodrigo.noll@hotmail.com
\end{abstract}

\section{RESUMO:}

Visando contribuir para o fortalecimento do uso adequado de fitoterápicos na Atenção Primária à Saúde, apresenta-se resultado de estudo etnobotânico e etnofarmacológico sobre o uso de plantas medicinais junto à comunidade da área de abrangência da Unidade de Saúde da Família Itambezinho (Campo Largo, Paraná, Brasil). A população amostral foi composta por 31 famílias, sendo que o maior número de entrevistados foram mulheres que possuíam entre 18 e 80 anos de idade, com escolaridade inferior a 8 anos de estudo e renda familiar inferior a 2 salários mínimos. Foram registradas 426 referências etnobotânicas junto aos entrevistados, associadas a 120 espécies predominantemente herbáceas. Dentre as plantas identificadas, as mais citadas para uso geral foram Mentha arvensis L. (35 citações), Melissa officinalis L. (21), Ruta graveolens L. (15), Zingiber officinale Roscoe (14) e Tanacetum vulgare L. (12). As informações etnobotânicas coletadas foram analisadas comparativamente ao exposto em distintas fontes impressas e eletrônicas, no sentido de identificar incongruências quanto a indicações de usos e também riscos de utilização inapropriada.

Palavras-chave: Atenção Primária à Saúde; Etnobotânica; Etnofarmacologia; Fitoterapia; Terapias Complementares.

\section{ABSTRACT:}

To contribute to the strengthening of the appropriate use of herbal medicines in primary health care presents results of the ethnobotanical and ethnopharmacological study on the use of medicinal plants with the area covered by the Family Health Care Unit Itambezinho (Campo Largo, Paraná, Brazil). The sample population was composed of 31 families, with the largest number of respondents was female, aged between 18 and 80 years old, with less than 8 years of schooling and family income less than 2 minimum wages. A total of 426 ethnobotanical references were registered among the interviewees, associated with 120 predominantly herbaceous species. Among the identified plants, the most frequently cited for general use were Mentha arvensis L. (35 citations), Melissa officinalis L. (21), Ruta graveolens L. (15), Zingiber officinale Roscoe (14) and Tanacetum vulgare L. (12). The collected ethnobotanical information was analyzed comparatively to the one exposed in different printed and electronic sources, in order to identify inconsistencies as to indications of uses and also risks of inappropriate use.

Keywords: Primary Health Care; Ethnobotany; Ethnopharmacology; Phytotherapy; Complementary Therapies. 


\section{INTRODUÇÃO}

As Práticas Integrativas e Complementares (PIC) em saúde constituem a denominação recente do Ministério da Saúde (MS) para a medicina tradicional e complementar (MTC), em suas ricas aplicações no Brasil. Considerado um campo de saberes e cuidados, representa um quadro extremamente múltiplo e sincrético, articulando um número crescente de métodos diagnóstico-terapêuticos, tecnologias leves, filosofias orientais, práticas religiosas, em estratégias sensíveis de vivência corporal e de autoconhecimento. Este campo constitui um fenômeno crescente no Brasil contemporâneo, visto que tais recursos têm sido apropriados e difundidos, além dos serviços públicos de saúde, por clínicas particulares, comunidades tradicionais, igrejas, movimentos sociais e entidades não governamentais (ANDRADE; DA COSTA, 2010).

As plantas medicinais e seus derivados estão entre os principais recursos terapêuticos da MTC. Estas vêm, há anos, sendo utilizadas pela população brasileira tanto nas práticas populares, quanto na medicina tradicional e nos programas públicos de fitoterapia no Sistema Único de Saúde (SUS), alguns com mais de 20 anos de existência (BRASIL, 2012).

Entre as PIC no SUS, as plantas medicinais e a fitoterapia são as mais presentes no Sistema, segundo diagnóstico do MS, e a maioria das experiências ocorre na atenção primária à saúde (BRASIL, 2012). O pluralismo diagnóstico-terapêutico que as PIC promovem, contribui para a integralidade na atenção à saúde, um dos princípios do SUS. Esta confluência favorece o reconhecimento de outros saberes, cuidados e práticas sanitárias, que, em parte, são o motivo do crescimento intenso dessas modalidades não biomédicas no Brasil e em diversos outros países (ANDRADE; DA COSTA, 2010).

Segundo a Organização Mundial da Saúde (OMS), até 2006, cerca de 85\% das pessoas do mundo utilizavam plantas medicinais para tratamento de saúde, e embora a medicina moderna esteja bem desenvolvida na maior parte do mundo, grande parte da população dos países em desenvolvimento depende da medicina tradicional para sua atenção primária, sendo que $80 \%$ desta população utiliza práticas tradicionais nos seus cuidados básicos de saúde, e aproximadamante $85 \%$ da medicina tradicional envolve o uso de extratos de plantas (OLIVEIRA et al., 2006; BRASIL, 2006a). 
No final da década de 1970, a OMS criou o Programa de Medicina Tradicional, objetivando a formulação de políticas públicas na área. No Brasil, a legitimação e a institucionalização dessas abordagens de atenção à saúde iniciaram-se a partir da década de 1980, após a criação do SUS (BRASIL, 2015). Neste sentido, destaca-se a implementação da Política Nacional de Práticas Integrativas e Complementares (PNPIC) no SUS, e da Política Nacional de Plantas Medicinais e Fitoterápicos (PNPMF), ambas aprovadas no ano de 2006 (BRASIL, 2006b; BRASIL, 2006c).

A implantação de determinadas políticas de saúde depende do conhecimento de fatores que podem interferir no processo saúde-doença da população. Dessa forma, o modo como as pessoas vivem, seus valores, crenças e costumes são informações essenciais que podem subsidiar a construção da situação da saúde local e a orientação do modelo de atenção (TOMAZZONI et al., 2006).

Dado o aumento crescente da utilização de medicinas tradicionais e complementares, há necessidade de que os profissionais de saúde estejam aptos a informar e atender os pacientes, reconhecer efeitos colaterais, interações medicamentosas e praticar as medicinas complementares isoladas ou associadas às medicinas convencionais com segurança (PENNAFORT et al., 2012), bem como realizar notificações de eventos adversos no Sistema Nacional de Notificações para a Vigilância Sanitária (NOTIVISA).

Neste contexto, o saber popular poderia ser utilizado como base para a pesquisa científica sobre plantas medicinais, contribuindo com os profissionais da área da saúde no sentido de buscar subsídios para a introdução de espécies em programas de fitoterapia na rede de atendimento básico, além de contribuir para o sistema local de saúde e ajudar a desenvolver o potencial econômico inerente às plantas de valor medicinal (NEGRELLE et al., 2007).

Atualmente, o conhecimento sobre o poder curativo das plantas não pode mais ser considerado apenas como tradição passada de pais para filhos, e sim como ciência que vem sendo estudada, aperfeiçoada e aplicada ao longo dos tempos, por diversas culturas (TOMAZZONI et al., 2006). Neste sentido, vários estudos etnobotânicos e etnofarmacológicos têm sido realizados no sentido de evidenciar o uso de plantas medicinais em comunidades rurais no sul do Brasil (JACOBY et al., 2002; CAETANO et al., 2003; NEGRELLE; FORNAZZARI, 2007). 
Frente a esta perspectiva, apresenta-se resultado de levantamento etnobotânico e etnofarmacológico sobre o uso de plantas medicinais com finalidade terapêutica junto à comunidade da área de abrangência da Unidade de Saúde da Família (USF) Itambezinho (Campo Largo, Paraná, Brasil), visando contribuir para o fortalecimento do uso adequado de fitoterápicos na atenção primária à saúde.

Especificamente, visou-se: a) identificar as espécies vegetais utilizadas, forma e indicação de uso, assim como o local de obtenção das mesmas; b) comparar o emprego de plantas medicinais pela população estudada com o descrito na literatura, de modo a identificar incongruências e riscos de utilização inapropriada; c) avaliar potenciais determinantes da utilização destas plantas medicinais (fator socioeconômico, sexo, idade ou outro) e a partir da análise dos dados obtidos, apresentar recomendações a distintos atores sociais visando subsidiar o planejamento e introdução do uso de fitoterápicos na Atenção Primária à Saúde.

\section{MATERIAL E MÉTODOS}

Este estudo seguiu as normas da Resolução 466/12 do Conselho Nacional de Saúde e teve início após a aprovação do projeto pelo Comitê de Ética em Pesquisas do Setor de Ciências da Saúde da Universidade Federal do Paraná (UFPR), parecer CEP/SDPB nำ1.343.161, de 30 de novembro de 2015.

O estudo foi desenvolvido junto à comunidade da área de abrangência da USF Itambezinho inserida em região rural, distando cerca de $40 \mathrm{~km}$ da região central do município sede - Campo Largo (PR) (2527' 31" S; 49³1' 42” W; 956m s.n.m.) (IPARDES, 2016). A cobertura vegetal característica desta região é classificada como Floresta Ombrófila Mista ou Floresta com Araucária (IBGE, 2012).

O município de Campo Largo é um dos 29 municípios que compõem a Região Metropolitana de Curitiba (RMC), ocupa uma área geográfica de $1.282,564 \mathrm{~km}^{2}$, e possui 124.098 habitantes, população estimada em 2015 (IPARDES, 2016).

Inicialmente denominada Mini Posto de Saúde Santo Antônio, inaugurada em 09 de setembro de 1987, a unidade de saúde da região do Itambezinho funcionava junto à escola da região e possuía atendimento médico apenas aos sábados. Posteriormente, o atendimento passou a ser realizado duas vezes por semana e não havia atendimento 
odontológico. Em nova construção, a atual unidade foi inaugurada em junho de 2004, sob nome de Unidade de Saúde Itambezinho e durante o desenvolvimento da pesquisa, dispunha de uma equipe da Estratégia Saúde da Família com equipe de Saúde Bucal modalidade I, composta por 1 médico clínico geral, 1 enfermeiro, 1 cirurgião-dentista, 1 auxiliar de enfermagem, 1 auxiliar de saúde bucal e 4 agentes comunitários de saúde. A USF contava ainda com 1 motorista e 1 auxiliar de serviços gerais.

No período do estudo, a USF prestava atendimento a uma população de aproximadamente 1.100 habitantes, pertencentes a 346 famílias, englobando indivíduos adultos, entre 20 e 59 anos (53\%); seguida de crianças, adolescentes e jovens, entre 0 e 19 anos (32\%) e idosos, acima de 60 anos (15\%).

Estas famílias estavam distribuídas em quatro microáreas, totalizando 25 comunidades rurais, a saber: a) microárea 1 - 94 famílias distribuídas nas comunidades de Itambezinho (parcial), Prata, Roça Nova, Água Comprida, Barreiro, Barra e São João do Povinho; b) microárea 2 - 87 famílias, nas comunidades de Itambezinho (parcial), Passa Três, Rio Bonito, Vargedo, Campina do Vargedo, Varanal, Chacrinha, Rio dos Matos e Colônia dos Russos; c) microárea 3 - 76 famílias, nas comunidades de Taquaral, Faxina, Pinhal, Descalvado e Jacuí; d) microárea 4 - 89 famílias, nas comunidades de Dom Rodrigo, Cerrado, Passo Fundo, Camarinhas e Retiro Grande, totalizando 89 famílias.

A densidade populacional entre as comunidades rurais era bastante diversificada, sendo "Itambezinho" o maior núcleo populacional com 80 famílias, e "Passa Três" o menor, com 2 famílias.

O universo amostral correspondeu a 31 famílias residentes na área de abrangência da USF, aleatoriamente selecionadas entre aquelas previamente identificadas como usuárias de plantas medicinais, por meio das fichas do sistema e-SUS Atenção Básica, utilizadas em visitas domiciliares pelos Agentes Comunitários de Saúde. Segundo essas fichas, a população residente na área de abrangência da USF que informou fazer uso de plantas medicinais foi de $83,16 \%$. A suficiência amostral foi determinada pela curva de acumulação de espécies (SCHILLING; BATISTA, 2008; MOTA et al., 2014).

A coleta de dados deu-se por entrevistas semiestruturadas realizadas de dezembro de 2015 a julho de 2016, com o membro da família maior de idade que estava presente na residência e se disponibilizava para tal atividade. Após apresentação e explanação inicial acerca do objetivo da pesquisa, e concordância do entrevistado com assinatura do Termo 
de Consentimento Livre e Esclarecido (TCLE), a entrevista era iniciada. Utilizou-se roteiro básico previamente testado quanto à validade e confiabilidade (GIL, 2002). Além da informação sobre a identificação pessoal (nome completo, endereço, sexo, idade, escolaridade, ocupação, renda familiar, dados sobre os membros da família, dados sobre tipo de residência), durante a entrevista foram anotados dados sobre plantas medicinais utilizadas com finalidade terapêutica, modo de uso, finalidade e fonte de obtenção deste conhecimento.

$\mathrm{Na}$ análise de dados, as indicações de uso popular foram substituídas pelas propriedades terapêuticas correspondentes, por exemplo: para "dor", utilizou-se "analgésico"; para "inflamação", utilizou-se "anti-inflamatório"; para “infecção", utilizou-se "antimicrobiano" (INFOPÉDIA, 2017).

Sempre que possível, realizou-se a coleta e herborização das plantas citadas. A identificação do material coletado seguiu os padrões da taxonomia clássica, feita com base em caracteres morfológicos vegetativos e florais e utilizando-se, quando possível, vários exemplares (FIDALGO; BONONI, 1989). As determinações foram efetuadas por meio de chaves analíticas e comparações com materiais depositados nos herbários UPCB e MBM. A confirmação das determinações foi efetuada por equipe técnica do Museu Botânico Municipal de Curitiba (PR).

As informações etnobotânicas coletadas foram analisadas comparativamente ao exposto em distintas fontes impressas e eletrônicas, no sentido de identificar incongruências quanto a indicações de usos e também riscos de utilização inapropriada.

Os dados coletados foram organizados e quantificados por meio de planilhas do aplicativo Microsoft Excel 2013. Para análise estatística dos dados, foi utilizado o software Epi Info Versão 7.1.5.0.

Para avaliar os potenciais determinantes do uso de plantas medicinais com finalidade terapêutica (sexo, idade, renda familiar e escolaridade), foram considerados os dados dos 89 moradores integrantes das 31 famílias participantes da pesquisa. Foi utilizado o teste Qui-Quadrado de Pearson, com correção pelo teste exato de Fisher quando necessário, sendo adotado em todos os casos, o nível de significância 0,05 ( $p=0,05)$.

\section{RESULTADOS}

A caracterização socioeconômica aponta que $77,42 \%$ dos participantes da pesquisa 
pertencem ao sexo feminino, sendo que a idade média dos entrevistados foi de 51 anos \pm 15 (idade máxima $=80$, idade mínima $=18$, variância $=224,86$ ). A média de moradores por residência foi de $2,87 \pm 1,31$ (valor máximo $=6$, valor mínimo $=1$, variância $=1,71$ ).

A renda familiar predominante foi de 1 a 2 salários mínimos (83,87\% das famílias), registrando-se 16,13\% famílias com renda de 3 a 4 salários mínimos. Com relação à escolaridade, $61,29 \%$ relataram possuir o $1^{\circ}$ grau incompleto, $19,35 \%$ o $2^{\circ}$ grau completo, $9,68 \%$ o $1^{\circ}$ grau completo e $9,68 \%$ o $2^{\circ}$ grau incompleto. As religiões predominantes foram: católica $(87,1 \%)$ e evangélica (12,9\%). Quando perguntados sobre a ocupação, observouse igual proporcionalidade entre os entrevistados que se declararam serem aposentados ou pensionistas (29\%) e donas de casa ("do lar") (29\%). Vários outros tipos de atividades foram reportados pelos demais entrevistados, incluindo serviços gerais $(12,9 \%)$ e outros (29\%) (agente comunitário de saúde, autônomo, auxiliar de enfermagem, chacareiro, lavrador, merendeira, motorista e um desempregado).

Quanto ao tipo de moradia, 64,52\% das residências correspondiam a construções em alvenaria e $35,48 \%$ em madeira. Todas as residências dispunham de energia elétrica fornecida pela rede pública. Nenhuma das famílias visitadas possuía acesso a água fluoretada da rede pública, sendo o abastecimento de água, em 74,19\% das residências, proveniente de nascente superficial próxima e $25,81 \%$ de poço perfurado na propriedade. Apenas 35,48\% dos entrevistados relataram possuir telefone residencial e nenhum possuía acesso à internet em casa. Em 96,77\% das residências, a forma de acesso se deu via estrada de chão, devido à área de abrangência da USF estar localizada em região rural.

Dentre os 89 integrantes das famílias participantes da pesquisa, verificou-se que $67,42 \%$ faziam uso de plantas medicinais, sendo 53,93\% do sexo masculino e $46,07 \%$ do sexo feminino, com idade média de 41 anos \pm 21 (idade máxima $=83$, idade mínima $=0$, variância $=450,78)$. Identificou-se o sexo, a faixa etária e a escolaridade como principais determinantes do uso de plantas medicinais com finalidade terapêutica, sendo este uso predominantemente vinculado ao sexo feminino, à faixa etária acima de 50 anos, e à baixa escolaridade (máximo $1^{\circ}$ grau completo). A renda familiar não foi identificada como determinante do uso de plantas medicinais com esta finalidade, conforme demonstrado na Tabela 1. 
Tabela 1. Variáveis utilizadas na associação ao uso de plantas medicinais em levantamento etnobotânico e etnofarmacológico realizado junto à comunidade da área de abrangência da usf itambezinho (campo largo / pr, dez. 2015 a jul. 2016)

\begin{tabular}{|c|c|c|c|c|c|c|c|}
\hline \multirow{2}{*}{ Variável } & \multicolumn{2}{|c|}{ Usa PM } & \multicolumn{2}{|c|}{ Não usa PM } & \multirow{2}{*}{ Valor de $p$} & \multicolumn{2}{|c|}{ Total } \\
\hline & $\mathrm{N}$ & $\%$ & $\mathrm{n}$ & $\%$ & & $\mathrm{~N}$ & $\%$ \\
\hline Sexo & & & & & $0,0018^{*}$ & & \\
\hline Feminino & 35 & 58,33 & 6 & 20,69 & & 41 & 46,07 \\
\hline Masculino & 25 & 41,67 & 23 & 79,31 & & 48 & 53,93 \\
\hline Faixa etária & & & & & $0,0008^{*}$ & & \\
\hline $0-49$ anos & 28 & 46,67 & 25 & 86,21 & & 53 & 59,55 \\
\hline$\geq 50$ anos & 32 & 53,33 & 4 & 13,79 & & 36 & 40,45 \\
\hline Renda familiar & & & & & $0,1645^{* *}$ & & \\
\hline 1 a 2 SM & 52 & 86,63 & 22 & 75,86 & & 74 & 83,15 \\
\hline 3 a 4 SM & 8 & 13,33 & 7 & 24,14 & & 15 & 16,85 \\
\hline Escolaridade & & & & & $0,0148^{*}$ & & \\
\hline 1o grau compl. (máx.) & 46 & 76,67 & 14 & 48,28 & & 60 & 67,42 \\
\hline 2o grau incompl. (mín.) & 14 & 23,33 & 15 & 51,72 & & 29 & 32,58 \\
\hline
\end{tabular}

*Teste qui-quadrado de Pearson; **Teste exato de Fisher.

(PM = plantas medicinais; $S M=$ salário mínimo; máx. = máximo; mín. = mínimo $)$

Os principais motivos relacionados ao uso de plantas medicinais citados pelos participantes da pesquisa foram: a eficácia (71\%), a praticidade $(45 \%)$ e a confiabilidade (42\%). Outros motivos citados foram a sua ação complementar a medicamentos sintéticos (3\%) e o baixo custo (3\%). Estas questões permitiam múltiplas opções, por isso o entrevistado que respondeu eficácia pode não ter respondido confiabilidade. Desta forma, não podemos afirmar que apenas $42 \%$ dos entrevistados confiam na prática relacionada ao uso de plantas medicinais. A quase totalidade dos entrevistados (97\%) explicitou não evidenciar as plantas medicinais como potencialmente danosas ou com efeitos colaterais. Em nenhum dos domicílios visitados foi indicado algum efeito adverso quando do uso das plantas citadas.

Destaca-se que em $80,65 \%$ dos domicílios visitados, o uso de plantas medicinais associadas a outros medicamentos foi relatado, sendo que 51,61\% dos entrevistados informaram não ter comunicado ao profissional de saúde o uso de plantas medicinais. Quando questionados sobre a quem a família recorre em caso de doença, a totalidade dos entrevistados informou recorrer ao médico e às plantas medicinais. 38,71\% informaram 
recorrer diretamente à farmácia, 35,48\% ao vizinho, 22,58\% à benzedeira, e 6,45\% relataram buscar informações na internet. A quase totalidade (96,77\%) dos entrevistados informou que substituiriam medicamentos convencionais por plantas medicinais, se houvesse a comprovação científica desta prática integrativa e complementar.

O uso de plantas com finalidade terapêutica foi referenciado como advindo de tradição familiar por $89,44 \%$ dos participantes da pesquisa, sendo que $8,69 \%$ foi advindo do círculo de amizades e vizinhança, e 1,88\% dos participantes da pesquisa referenciaram o uso advindo de outras formas de recomendações, tais como orientação médica, farmacêutica, sugestões dos patrões, ou conhecimento proveniente de leitura em livros.

Foram registradas 426 citações de plantas medicinais para uso geral, associadas a 120 espécies predominantemente herbáceas $(65,96 \%)$. O uso de material fresco foi citado em $88,97 \%$ dos registros. A folha e parte aérea corresponderam às partes vegetais com predominância de uso $(44,84 \%$ e $31,22 \%$ das citações, respectivamente). As formas de preparo mais referenciadas foram a infusão $(53,05 \%)$ e decocção $(27 \%)$, entre outras. $O$ local de aquisição predominante foi o quintal (92,49\% das citações), seguido de aquisição no comércio $(4,46 \%)$, no mato $(2,11 \%)$ e outros locais $(0,94 \%)$, tais como outra chácara da família, vizinhos ou por meio de familiares. Dentre as plantas medicinais citadas, $67,14 \%$ foram indicadas como de uso em caso de sintoma, $26,06 \%$ raramente e $6,81 \%$ como frequentemente utilizadas.

A média de citações de plantas medicinais por entrevista foi de 13,74 $\pm 11,39$ (valor máximo $=37$, valor mínimo $=2$, variância $=129,73$ )

As dez espécies com maior frequência de citações $(n=426)$ foram: Mentha arvensis L. (35 citações, $8,22 \%$ do total), Melissa officinalis L. (21 citações, 4,93\% do total), Ruta graveolens L. (15 citações, 3,52\% do total), Zingiber officinale Roscoe (14 citações, 3,29\% do total), Tanacetum vulgare L. (12 citações, $2,82 \%$ do total), Rosmarinus officinalis L. (12 citações, $2,82 \%$ do total), Foeniculum vulgare Mill. (11 citações, 2,58\% do total), Achillea millefolium L. (11 citações, 2,58\% do total), Cymbopogon citratus (DC.) Stapf (11 citações, $2,58 \%$ do total) e Plantago major L. (10 citações, $2,35 \%$ do total).

A Tabela 2 apresenta as espécies vegetais mais referenciadas para uso geral, número de citações $(n=426)$, parte utilizada, hábito, forma de uso, modo de preparo, finalidade terapêutica citada e bioatividade de acordo com a literatura. A maioria das espécies identificadas para uso geral estava associada a mais de uma indicação terapêutica, como por exemplo, ação antimicrobiana e anti-inflamatória. 
Tabela 2. Espécies vegetais referenciadas com finalidade terapêutica em levantamento etnobotânico e etnofarmacológico realizado junto à comunidade da área de abrangência da usf itambezinho (campo largo / pr, dez. 2015 a jul. 2016)

\begin{tabular}{|c|c|c|c|c|c|c|c|}
\hline $\begin{array}{l}\text { FAMÍLIA } \\
\text { Espécie } \\
\text { (nome popular) }\end{array}$ & $\begin{array}{l}\text { № cit. } \\
\text { (\%) }\end{array}$ & $\begin{array}{l}\text { Parte } \\
\text { utilizada } \\
\text { (\% no cit.) }\end{array}$ & $\begin{array}{l}\text { Hábito } \\
\text { (\% no cit.) }\end{array}$ & $\begin{array}{l}\text { Forma de } \\
\text { uso } \\
\text { (\% no cit.) }\end{array}$ & $\begin{array}{l}\text { Modo de } \\
\text { preparo } \\
\text { (\% no cit.) }\end{array}$ & $\begin{array}{l}\text { Finalidade terapêutica } \\
\text { citada } \\
\left.\text { (\% } \mathrm{n}^{\circ} \text { cit. }\right)\end{array}$ & Bioatividade de acordo com a literatura \\
\hline $\begin{array}{l}\text { ALISMATACEAE } \\
\text { Echinodorus grandiflorus } \\
\text { (Cham. \& Schltdl.) Micheli } \\
\text { (chapéu de couro) }\end{array}$ & $\begin{array}{c}1 \\
(0,23)\end{array}$ & $\begin{array}{l}\text { Folha } \\
(100)\end{array}$ & $\begin{array}{l}\text { Herbácea } \\
\qquad(100)\end{array}$ & Fresca (100) & Infusão (100) & Antimicrobiano (100) & $\begin{array}{l}\text { Efeito anti-hipertensivo em ratos } \\
\text { espontaneamente hipertensos (LESSA et al., } \\
\text { 2008) }\end{array}$ \\
\hline $\begin{array}{l}\text { AMARANTHACEAE } \\
\text { Alternanthera brasiliana (L.) } \\
\text { Kuntze } \\
\text { (penicilina, aspirina) }\end{array}$ & $\begin{array}{c}8 \\
(1,88)\end{array}$ & $\begin{array}{l}\text { Folha } \\
(87,50), \\
\text { folha e } \\
\text { caule } \\
(12,50)\end{array}$ & $\begin{array}{l}\text { Herbácea } \\
\text { (100) }\end{array}$ & $\begin{array}{c}\text { Fresca } \\
(87,50), \text { seca } \\
(12,50)\end{array}$ & $\begin{array}{c}\text { Infusão }(62,50), \\
\text { decocção }(25), \\
\text { maceração } \\
(12,50)\end{array}$ & $\begin{array}{c}\text { Antimicrobiano }(62,50) \text {, } \\
\text { anti-inflamatório } \\
(12,50) \text {, antipirético } \\
(12,50), \text { analgésico }(25)\end{array}$ & $\begin{array}{l}\text { Atividade analgésica, antiedematogênica e } \\
\text { antiproliferativa de linfócitos (DELAPORTE et } \\
\text { al., 2005); propriedades anti-inflamatória, } \\
\text { analgésica, antiviral (TRACZ et al., 2014), } \\
\text { béquica, diurética, digestiva, depurativa (SILVA } \\
\text { et al., 2009); extrato das folhas apresenta } \\
\text { atividade analgésica, anti-inflamatória e } \\
\text { cicatrizante (ROCHA, 2013) }\end{array}$ \\
\hline $\begin{array}{l}\text { AMARANTHACEAE } \\
\text { Beta vulgaris L. } \\
\text { (beterraba) }\end{array}$ & $\begin{array}{c}1 \\
(0,23)\end{array}$ & Raiz (100) & $\begin{array}{l}\text { Herbácea } \\
\text { (100) }\end{array}$ & Fresca (100) & Xarope (100) & $\begin{array}{l}\text { Doenças respiratórias } \\
(100) \text {, anemia }(100)\end{array}$ & NC \\
\hline $\begin{array}{l}\text { AMARANTHACEAE } \\
\text { Dysphania ambrosioides (L.) } \\
\text { Mosyakin \& Clemants } \\
\text { (erva de santa maria) }\end{array}$ & $\begin{array}{c}3 \\
(0,70)\end{array}$ & $\begin{array}{l}\text { Folha } \\
(100)\end{array}$ & $\begin{array}{l}\text { Herbácea } \\
\text { (100) }\end{array}$ & Fresca (100) & $\begin{array}{l}\text { Infusão }(66,67), \\
\text { decocção } \\
(33,33)\end{array}$ & $\begin{array}{l}\text { Anti-helmíntico }(100) \\
\text { calmante }(33,33)\end{array}$ & $\begin{array}{l}\text { Atividade antitumoral, antipirética, analgésica, } \\
\text { anti-inflamatória, antifúngica, anti-helmíntica e } \\
\text { antiprotozoária (SÁ et al., 2016) }\end{array}$ \\
\hline $\begin{array}{l}\text { AMARANTHACEAE } \\
\text { Gomphrena globosa L. } \\
\text { (perpétua roxa) }\end{array}$ & $\begin{array}{c}1 \\
(0,23)\end{array}$ & $\begin{array}{c}\mathrm{F} \\
\text { Ior }(100)\end{array}$ & $\begin{array}{l}\text { Herbácea } \\
\text { (100) }\end{array}$ & Fresca (100) & Infusão (100) & $\begin{array}{c}\text { Distúrbios } \\
\text { cardiovasculares (100) }\end{array}$ & $\begin{array}{l}\text { Atividade hipotensora por redução da pressão } \\
\text { arterial, sem alteração da frequência cardíaca } \\
\text { (ARCANJO et al., 2011) }\end{array}$ \\
\hline $\begin{array}{l}\text { AMARANTHACEAE } \\
\text { Pfaffia glomerata (Spreng.) } \\
\text { Pedersen } \\
\text { (anador, dipirona) }\end{array}$ & $\begin{array}{c}2 \\
(0,47)\end{array}$ & $\begin{array}{l}\text { Parte } \\
\text { aérea } \\
(100)\end{array}$ & $\begin{array}{l}\text { Herbácea } \\
(50), \\
\text { arbusto } \\
(50)\end{array}$ & Fresca (100) & $\begin{array}{l}\text { Infusão (50), } \\
\text { decocção (50) }\end{array}$ & Analgésico (100) & $\begin{array}{l}\text { Efeitos analgésicos e anti-inflamatórios (NETO } \\
\text { et al., 2005) }\end{array}$ \\
\hline $\begin{array}{l}\text { AMARANTHACEAE } \\
\text { Spinacia oleracea L. } \\
\text { (espinafre) }\end{array}$ & $\begin{array}{c}1 \\
(0,23)\end{array}$ & $\begin{array}{l}\text { Folha } \\
(100)\end{array}$ & $\begin{array}{l}\text { Herbácea } \\
\qquad(100)\end{array}$ & Fresca (100) & In natura $(100)$ & Uso geral (100) & NC \\
\hline $\begin{array}{l}\text { AMARYLLIDACEAE } \\
\text { Allium ampeloprasum L. } \\
\text { (alho-poró) }\end{array}$ & $\begin{array}{c}1 \\
(0,23)\end{array}$ & $\begin{array}{l}\text { Folha e } \\
\text { talo (100) }\end{array}$ & $\begin{array}{l}\text { Herbácea } \\
\qquad(100)\end{array}$ & Fresca $(100)$ & $\begin{array}{l}\text { Refogado } \\
\text { /cozimento } \\
(100)\end{array}$ & Enxaqueca (100) & $\begin{array}{l}\text { Propriedades antioxidantes (BERNAERT et al., } \\
\text { 2012) }\end{array}$ \\
\hline $\begin{array}{l}\text { AMARYLLIDACEAE } \\
\text { Allium sativum L. } \\
\text { (alho) }\end{array}$ & $\begin{array}{c}2 \\
(0,47)\end{array}$ & $\begin{array}{l}\text { Bulbo } \\
(100)\end{array}$ & $\begin{array}{l}\text { Herbácea } \\
\qquad(100)\end{array}$ & Fresca $(100)$ & $\begin{array}{c}\text { Maceração } \\
\text { (50), xarope } \\
(50)\end{array}$ & $\begin{array}{l}\text { Doenças respiratórias } \\
\qquad(100)\end{array}$ & $\begin{array}{l}\text { Coadjuvante no tratamento de hiperlipidemia, } \\
\text { hipertensão arterial leve, na prevenção de } \\
\text { alterações vasculares, como a aterosclerose, } \\
\text { nos sintomas de gripes e resfriados, bronquite } \\
\text { crônica, asma e expectorante (BRASIL, 2011; } \\
\text { BRASIL, 2016); acredita-se que tenha } \\
\text { propriedades anti-hipertensiva, antitrombótica, } \\
\text { fibrinolítica, antimicrobiana, antitumoral, } \\
\text { expectorante, antidiabética e hipolipemiante } \\
\text { (WILLIAMSON et al., 2012) }\end{array}$ \\
\hline $\begin{array}{l}\text { ANACARDIACEAE } \\
\text { Schinus terebinthifolius } \\
\text { Raddi } \\
\text { (aroeira) }\end{array}$ & $\begin{array}{c}1 \\
(0,23)\end{array}$ & $\begin{array}{l}\text { Folha e } \\
\text { caule } \\
(100)\end{array}$ & $\begin{array}{c}\text { Árvore } \\
(100)\end{array}$ & Fresca (100) & Infusão (100) & $\begin{array}{l}\text { Analgésico (100), anti- } \\
\text { inflamatório (100) }\end{array}$ & $\begin{array}{l}\text { Ação antimicrobiana, anti-inflamatória, } \\
\text { antiulcerogênica, atividade bactericida e } \\
\text { bacteriostática sobre S. mutans, S. mitis, S. } \\
\text { sobrinus, S. sanguis, L. caseie ação antifúngica } \\
\text { sobre C. albicans, C. tropicalis e C. krusei } \\
\text { (FRANCISCO, 2010); balsâmica, adstringente, } \\
\text { propriedades hemostáticas (GRANDI, 2014); } \\
\text { anti-inflamatório e cicatrizante ginecológico para } \\
\text { uso externo (BRASIL, 2011); efeito anti- } \\
\text { inflamatório, antipirético, adstringente, } \\
\text { analgésico e depurativo (BALEN, 2015) }\end{array}$ \\
\hline
\end{tabular}




\begin{tabular}{|c|c|c|c|c|c|c|c|}
\hline $\begin{array}{l}\text { APIACEAE } \\
\text { Foeniculum vulgare Mill. } \\
\text { (erva doce) }\end{array}$ & $\begin{array}{c}11 \\
(2,58)\end{array}$ & $\begin{array}{l}\text { Parte } \\
\text { aérea } \\
(100)\end{array}$ & $\begin{array}{l}\text { Herbácea } \\
\qquad(100)\end{array}$ & $\begin{array}{c}\text { Fresca } \\
(72,73), \\
\text { fresca ou } \\
\text { seca }(18,18) \text {, } \\
\text { seca }(9,09)\end{array}$ & $\begin{array}{l}\text { Infusão }(72,73) \\
\text { decocção } \\
(27,27)\end{array}$ & $\begin{array}{l}\text { Distúrbios } \\
\text { gastrintestinais }(36,36) \text {, } \\
\text { calmante }(36,36), \\
\text { refrescante }(9,09), \\
\text { doenças respiratórias } \\
(18,18) \text {, antitussígeno } \\
(45,45) \text {, fortificante } \\
(9,09) \text {, insônia }(9,09)\end{array}$ & $\begin{array}{l}\text { Ação antioxidante, hepatoprotetora, } \\
\text { espasmolítica, antibacteriana, diurética, } \\
\text { analgésica, antipirética; uso terapêutico } \\
\text { aprovado contra tosse, bronquite, dispepsias, } \\
\text { problemas gastrintestinais leves } \\
\text { (VENDRUSCOLO et al., 2005); carminativo, } \\
\text { espasmolítico (SILVA et al., 2009), } \\
\text { antiflatulento, antidispéptico e antiespasmódico } \\
\text { (BRASIL, 2011) }\end{array}$ \\
\hline $\begin{array}{l}\text { APOCYNACEAE } \\
\text { Tabernaemontana } \\
\text { catharinensis A. DC. } \\
\text { (para tudo) }\end{array}$ & $\begin{array}{c}1 \\
(0,23)\end{array}$ & $\begin{array}{l}\text { Folha } \\
(100)\end{array}$ & $\begin{array}{l}\text { Árvore } \\
(100)\end{array}$ & Fresca (100) & $\begin{array}{l}\text { Maceração } \\
\qquad(100)\end{array}$ & $\begin{array}{l}\text { Picada de aranha / } \\
\text { escorpião (100) }\end{array}$ & $\begin{array}{l}\text { O extrato possui atividade antimicrobiana in vitro } \\
\text { (GONÇALVES et al., 2011), e atuou } \\
\text { positivamente na diminuição das alterações no } \\
\text { tecido muscular esquelético de camundongos } \\
\text { submetidos ao envenenamento botrópico } \\
\text { experimental (BONI et al., 2011) }\end{array}$ \\
\hline $\begin{array}{l}\text { AQUIFOLIACEAE } \\
\text { Ilex paraguariensis A. St.-Hil. } \\
\text { (erva mate) }\end{array}$ & $\begin{array}{c}1 \\
(0,23)\end{array}$ & $\begin{array}{l}\text { Folha } \\
(100)\end{array}$ & $\begin{array}{l}\text { Herbácea } \\
\text { (100) }\end{array}$ & Seca (100) & Infusão (100) & Refrescante (100) & $\begin{array}{l}\text { Efeitos estimulantes, diuréticos e analgésicos, } \\
\text { que podem ser atribuídos à presença da cafeína } \\
\text { (WILLIAMSON et al., 2012) }\end{array}$ \\
\hline $\begin{array}{l}\text { ARACEAE } \\
\text { Colocasia esculenta (L.) } \\
\text { Schott. } \\
\text { (inhame) }\end{array}$ & $\begin{array}{c}2 \\
(0,47)\end{array}$ & Raiz (100) & $\begin{array}{l}\text { Liana } \\
(100)\end{array}$ & Fresca $(100)$ & $\begin{array}{l}\text { Decocção (50), } \\
\text { maceração (50) }\end{array}$ & $\begin{array}{c}\text { Depurativo (50), } \\
\text { antimicrobiano (50) }\end{array}$ & $\begin{array}{l}\text { Atividade antifúngica (REIS, 2011) e } \\
\text { antibacteriana (MIRANDA et al., 2015) }\end{array}$ \\
\hline $\begin{array}{l}\text { ARACEAE } \\
\text { Zantedeschia aethiopica (L.) } \\
\text { Spreng. } \\
\text { (copo de leite) }\end{array}$ & $\begin{array}{c}1 \\
(0,23)\end{array}$ & $\begin{array}{l}\text { Folha } \\
(100)\end{array}$ & $\begin{array}{l}\text { Herbácea } \\
\qquad(100)\end{array}$ & Fresca (100) & In natura (100) & Assadura (100) & $\begin{array}{l}\text { Os extratos exibiram propriedades } \\
\text { anticoagulantes (KEE et al., 2008) }\end{array}$ \\
\hline $\begin{array}{l}\text { ARAUCARIACEAE } \\
\text { Araucaria angustifólia } \\
\text { (Bertol.) Kuntze } \\
\text { (araucária, pinheiro) }\end{array}$ & $\begin{array}{c}2 \\
(0,47)\end{array}$ & $\begin{array}{l}\text { Casca } \\
(100)\end{array}$ & $\begin{array}{c}\text { Árvore } \\
(100)\end{array}$ & $\begin{array}{l}\text { Fresca }(50) \\
\text { Seca }(50)\end{array}$ & $\begin{array}{l}\text { Infusão (50), } \\
\text { decocção (50) }\end{array}$ & $\begin{array}{l}\text { Antimicrobiano (100), } \\
\text { distúrbios renais }(50)\end{array}$ & $\begin{array}{l}\text { Atividade antimicrobiana, antineoplásica, e foi } \\
\text { verificada atividade hemaglutinante para as } \\
\text { lecitinas presentes nos pinhões (MARTINS- } \\
\text { RAMOS et al. 2010) }\end{array}$ \\
\hline $\begin{array}{l}\text { ARISTOLOCHIACE-AE } \\
\text { Aristolochia triangularis } \\
\text { Cham. } \\
\text { (cipó mil homem, cipó } \\
\text { milome) }\end{array}$ & $\begin{array}{c}2 \\
(0,47)\end{array}$ & $\begin{array}{l}\text { Caule / } \\
\text { cipó (100) }\end{array}$ & $\begin{array}{l}\text { Liana } \\
(100)\end{array}$ & Seca (100) & Decocção (100) & $\begin{array}{l}\text { Antidiabético }(50) \text {, } \\
\text { distúrbios urinários } \\
(50) \text {, distúrbios } \\
\text { gastrintestinais (50), } \\
\text { doenças respiratórias } \\
\text { (50) }\end{array}$ & $\begin{array}{l}\text { Anti-helmíntica, sedativa, emenagoga, anti- } \\
\text { febril, anti-inflamatória, anti-reumática e } \\
\text { antisséptica (CORRÊA; BIASI, 2003) }\end{array}$ \\
\hline $\begin{array}{l}\text { ASPARAGACEAE } \\
\text { Drimia maritima Stearn } \\
\text { (cebola do mar) }\end{array}$ & $\begin{array}{c}2 \\
(0,47)\end{array}$ & $\begin{array}{l}\text { Bulbo } \\
(100)\end{array}$ & $\begin{array}{l}\text { Herbácea } \\
\text { (100) }\end{array}$ & Fresca (100) & $\begin{array}{l}\text { Maceração } \\
(100)\end{array}$ & $\begin{array}{c}\text { Distúrbios } \\
\text { gastrintestinais (50), } \\
\text { câncer (50) }\end{array}$ & $\begin{array}{l}\text { Dentre as atividades biológicas das espécies de } \\
\text { Drimia incluem efeitos anti-inflamatórios, } \\
\text { antioxidantes, antibacterianos, antivirais, } \\
\text { antifúngicos, sobre o sistema cardiovascular e } \\
\text { citotóxicos (BOZORGl et al., 2017) }\end{array}$ \\
\hline $\begin{array}{l}\text { ASPHODELACEAE } \\
\text { Aloe vera (L.) Burm. f. } \\
\text { (babosa) }\end{array}$ & $\begin{array}{c}8 \\
(1,88)\end{array}$ & $\begin{array}{l}\text { Folha } \\
(100)\end{array}$ & $\begin{array}{c}\text { Arbusto } \\
(100)\end{array}$ & Fresca (100) & $\begin{array}{l}\text { In natura } \\
(87,50) \text {, } \\
\text { decocção } \\
(12,50)\end{array}$ & $\begin{array}{l}\text { Queimadura }(62,50), \\
\text { passar no cabelo (50), } \\
\text { queda de cabelo (25), } \\
\text { distúrbios } \\
\text { gastrintestinais }(25), \\
\text { cicatrizante }(25), \\
\text { câncer }(12,50)\end{array}$ & $\begin{array}{l}\text { Ação cicatrizante (MORAIS et al., 2005; } \\
\text { SILVEIRA et al., 2008; BRASIL, 2011; BRASIL, } \\
\text { 2016), antibacteriana, antifúngica e antivirótica } \\
\text { (MORAIS et al., 2005; SILVEIRA et al., 2008); } \\
\text { em casos de queimaduras de primeiro e } \\
\text { segundo graus (BRASIL, 2016); o gel da babosa } \\
\text { apresenta propriedades anti-inflamatórias, } \\
\text { antitumorais, imunomoduladoras e } \\
\text { antibacterianas. Internamente, acredita-se que o } \\
\text { gel apresenta propriedades imunoestimuladoras } \\
\text { e moderado efeito analgésico, antioxidante e } \\
\text { hipoglicemiante (WILLIAMSON et al., 2012) }\end{array}$ \\
\hline $\begin{array}{l}\text { ASTERACEAE } \\
\text { Acanthospermum australe } \\
\text { (Loefl.) Kuntze } \\
\text { (erva tostão) }\end{array}$ & $\begin{array}{c}2 \\
(0,47)\end{array}$ & $\begin{array}{l}\text { Parte } \\
\text { aérea } \\
(100)\end{array}$ & $\begin{array}{l}\text { Herbácea } \\
\text { (100) }\end{array}$ & $\begin{array}{c}\text { Fresca } \\
(100)\end{array}$ & $\begin{array}{c}\text { Infusão (50), } \\
\text { decocção (50) }\end{array}$ & $\begin{array}{c}\text { Distúrbios } \\
\text { gastrintestinais }(100), \\
\text { distúrbios renais }(50), \\
\text { refrescante }(50)\end{array}$ & Atividade antibacteriana (BONELLA et al., 2011) \\
\hline $\begin{array}{l}\text { ASTERACEAE } \\
\text { Achillea millefolium L. } \\
\text { (novalgina, pronto alívio) }\end{array}$ & $\begin{array}{c}11 \\
(2,58)\end{array}$ & $\begin{array}{l}\text { Parte } \\
\text { aérea } \\
(90,91) \\
\text { planta } \\
\text { inteira } \\
(9,09)\end{array}$ & $\begin{array}{l}\text { Herbácea } \\
\text { (100) }\end{array}$ & Fresca (100) & $\begin{array}{l}\text { Infusão }(81,82) \text {, } \\
\text { decocção } \\
(9,09) \\
\text { maceração } \\
(9,09)\end{array}$ & $\begin{array}{l}\text { Analgésico }(63,64) \text {, } \\
\text { antipirético }(45,45) \text {, } \\
\text { doenças respiratórias } \\
(27,27) \text {, calmante } \\
(9,09) \text {, cicatrizante } \\
(9,09)\end{array}$ & $\begin{array}{l}\text { Seu óleo essencial possui propriedades } \\
\text { antioxidantes e antimicrobianas in vitro } \\
\text { (CANDAN et al., 2003); antidispéptico, } \\
\text { antiflatulento, anti-inflamatório, colerético e } \\
\text { antiespasmódico (BRASIL, 2011); atividades } \\
\text { anti-inflamatória e antiplaquetária } \\
\text { (WILLIAMSON et al., 2012) }\end{array}$ \\
\hline $\begin{array}{l}\text { ASTERACEAE } \\
\text { Achyrocline satureioides } \\
\text { (Lam.) DC. } \\
\text { (marcelinha) }\end{array}$ & $\begin{array}{c}1 \\
(0,23)\end{array}$ & Flor (100) & $\begin{array}{l}\text { Herbácea } \\
\text { (100) }\end{array}$ & Fresca (100) & Infusão (100) & Antitussígeno (100) & $\begin{array}{l}\text { Estomáquico, carminativo, antiespasmódico, } \\
\text { estomacal, diurético, cólicas intestinais, dores } \\
\text { de estômago, lavar feridas e úlceras, diarreias, } \\
\text { tônica e estimulante, indigestão e dores uterinas } \\
\text { (MENTZ; SCHENKEL, 1989); antidispéptico, } \\
\text { antiespasmódico e anti-inflamatório (BRASIL, } \\
\text { 2011) }\end{array}$ \\
\hline
\end{tabular}




\begin{tabular}{|c|c|c|c|c|c|c|c|}
\hline $\begin{array}{l}\text { ASTERACEAE } \\
\text { Ageratum conyzoides L. } \\
\text { (erva de são joão) }\end{array}$ & $\begin{array}{c}3 \\
(0,70)\end{array}$ & $\begin{array}{l}\text { Parte } \\
\text { aérea } \\
(100)\end{array}$ & $\begin{array}{l}\text { Herbácea } \\
\qquad(100)\end{array}$ & Fresca (100) & $\begin{array}{l}\text { Infusão }(66,67) \\
\text { decocção } \\
(33,33)\end{array}$ & $\begin{array}{c}\text { Antidepressivo } \\
(66,67), \text { calmante } \\
(33,33) \text {, distúrbios } \\
\text { gastrintestinais }(33,33)\end{array}$ & $\begin{array}{l}\text { Possível atividade cicatrizante, analgésica, } \\
\text { antipirética e anti-inflamatória (OKUNADE, } \\
\text { 2002) }\end{array}$ \\
\hline $\begin{array}{l}\text { ASTERACEAE } \\
\text { Arctium lappa L. } \\
\text { (badana, bardana) }\end{array}$ & $\begin{array}{c}2 \\
(0,47)\end{array}$ & $\begin{array}{l}\text { Folha } \\
(100)\end{array}$ & $\begin{array}{l}\text { Herbácea } \\
\text { (100) }\end{array}$ & $\begin{array}{l}\text { Fresca }(50) \\
\text { seca }(50)\end{array}$ & Decocção (100) & $\begin{array}{l}\text { Cicatrizante }(50) \text {, } \\
\text { antidiabético }(50)\end{array}$ & $\begin{array}{l}\text { Atividade antimicrobiana (PESSINI et al., 2003); } \\
\text { potencial propriedade anti-inflamatória (FANTE } \\
\text { et al., 2008); antidispéptico, diurético e anti- } \\
\text { inflamatório (BRASIL, 2011); as liganas e a } \\
\text { arctiina, constituintes da planta, apresentam } \\
\text { efeitos antiproliferativos in vitro e efeitos } \\
\text { estrogênicos, respectivamente (WILLIAMSON } \\
\text { et al., 2012) }\end{array}$ \\
\hline $\begin{array}{l}\text { ASTERACEAE } \\
\text { Artemisia absinthium L. } \\
\text { (losna) }\end{array}$ & $\begin{array}{c}4 \\
(0,94)\end{array}$ & $\begin{array}{l}\text { Folha } \\
(100)\end{array}$ & $\begin{array}{l}\text { Herbácea } \\
\qquad(100)\end{array}$ & Fresca (100) & Infusão (100) & $\begin{array}{l}\text { Distúrbios } \\
\text { gastrintestinais (100) }\end{array}$ & $\begin{array}{l}\text { Possível atividade analgésica e anti-inflamatória } \\
\text { (AHMAD et al., 1992) }\end{array}$ \\
\hline $\begin{array}{l}\text { ASTERACEAE } \\
\text { Artemisia alba Turra } \\
\text { (cânfora) }\end{array}$ & $\begin{array}{c}4 \\
(0,94)\end{array}$ & $\begin{array}{l}\text { Folha } \\
(100)\end{array}$ & $\begin{array}{l}\text { Herbácea } \\
\qquad(100)\end{array}$ & Fresca (100) & $\begin{array}{l}\text { Infusão (75), } \\
\text { decocção (25) }\end{array}$ & $\begin{array}{l}\text { Analgésico }(50), \\
\text { contusão }(25), \\
\text { refrescante }(25), \\
\text { distúrbios } \\
\text { gastrintestinais }(25)\end{array}$ & $\begin{array}{l}\text { Carminativa, diurética, colagoga (SILVA et al., } \\
\text { 2009) }\end{array}$ \\
\hline $\begin{array}{l}\text { ASTERACEAE } \\
\text { Artemisia vulgaris L. } \\
\text { (artemisia) }\end{array}$ & $\begin{array}{c}5 \\
(1,17)\end{array}$ & $\begin{array}{l}\text { Parte } \\
\text { aérea } \\
(100)\end{array}$ & $\begin{array}{l}\text { Herbácea } \\
\text { (100) }\end{array}$ & $\begin{array}{l}\text { Fresca }(80) \\
\text { seca }(20)\end{array}$ & $\begin{array}{l}\text { Decocção (60), } \\
\text { infusão }(40)\end{array}$ & $\begin{array}{c}\text { Recaída }(80), \\
\text { distúrbios } \\
\text { gastrintestinais }(60) \text {, } \\
\text { enxaqueca }(20)\end{array}$ & $\begin{array}{l}\text { Alívio de cólicas intestinais e menstruais, e como } \\
\text { digestivo (MALINOWSKI et al., 2007); } \\
\text { propriedades anti-inflamatórias, pode } \\
\text { apresentar efeito anti-hipertensivo (TIGNO et } \\
\text { al., 2000; RODRIGUES et al., 2011) }\end{array}$ \\
\hline $\begin{array}{l}\text { ASTERACEAE } \\
\text { Baccharis crispa Spreng. } \\
\text { (carqueja) }\end{array}$ & $\begin{array}{c}3 \\
(0,70)\end{array}$ & $\begin{array}{l}\text { Parte } \\
\text { aérea } \\
(100)\end{array}$ & $\begin{array}{l}\text { Herbácea } \\
\text { (100) }\end{array}$ & Fresca (100) & Infusão (100) & $\begin{array}{l}\text { Diurético }(66,67) \text {, } \\
\text { emagrecedor }(66,67)\end{array}$ & $\begin{array}{l}\text { Possível atividade anti-inflamatória, antioxidante } \\
\text { (ABAD; BERMEJO, 2007) e antidispéptica } \\
\text { (BRASIL, 2011) }\end{array}$ \\
\hline $\begin{array}{l}\text { ASTERACEAE } \\
\text { Bidens pilosa L. } \\
\text { (picão) }\end{array}$ & $\begin{array}{c}2 \\
(0,47)\end{array}$ & $\begin{array}{l}\text { Parte } \\
\text { aérea } \\
(100)\end{array}$ & $\begin{array}{l}\text { Herbácea } \\
\qquad(100)\end{array}$ & Fresca (100) & $\begin{array}{l}\text { Infusão (50), } \\
\text { decocção (50) }\end{array}$ & $\begin{array}{l}\text { Antimicrobiano }(50), \\
\text { cicatrizante }(50), \\
\text { antidiabético }(50)\end{array}$ & $\begin{array}{l}\text { Antibiótica, hepatoprotetora, contra dor de } \\
\text { cabeça (SILVA et al., 2009) }\end{array}$ \\
\hline $\begin{array}{l}\text { ASTERACEAE } \\
\text { Calendula officinalis } \mathrm{L} \text {. } \\
\text { (calêndula, arnica) }\end{array}$ & $\begin{array}{c}4 \\
(0,70)\end{array}$ & $\begin{array}{l}\text { Parte } \\
\text { aérea } \\
\text { (75), flor } \\
\text { (25) }\end{array}$ & $\begin{array}{l}\text { Herbácea } \\
\qquad(100)\end{array}$ & $\begin{array}{l}\text { Fresca }(75) \\
\text { seca }(25)\end{array}$ & $\begin{array}{c}\text { Maceração } \\
\text { (50), infusão } \\
\text { (25), decocção } \\
\text { (25) }\end{array}$ & $\begin{array}{c}\text { Cicatrizante (100), } \\
\text { antidiabético (25), } \\
\text { varizes (25), analgésico } \\
\text { (25) }\end{array}$ & $\begin{array}{l}\text { Para uso externo com ação anti-inflamatória, } \\
\text { cicatrizante (BRASIL, 2011; BRASIL, 2016), } \\
\text { antimicrobiana, antisséptica e sobre mucosite } \\
\text { bucal. Para tratamento de lesões de pele e } \\
\text { mucosas, promovendo a cicatrização e } \\
\text { modulando possíveis focos inflamatórios } \\
\text { (BRASIL, 2016); o gel possui atividade } \\
\text { antisséptica, anti-inflamatória e cicatrizante, } \\
\text { além de auxiliar no tratamento da acne e } \\
\text { inflamações em geral (BRASIL, 2011); utilizada } \\
\text { em produtos aplicados externamente para o } \\
\text { tratamento de ferimentos, queimaduras e } \\
\text { conjuntivite, além de ser utilizada no tratamento } \\
\text { de úlceras gástricas e duodenais, bem como } \\
\text { hemorroidas e veias varicosas (WILLIAMSON et } \\
\text { al. 2012) }\end{array}$ \\
\hline $\begin{array}{l}\text { ASTERACEAE } \\
\text { Chaptalia nutans (L.) Pol. } \\
\text { (dente de leão) }\end{array}$ & $\begin{array}{c}1 \\
(0,23)\end{array}$ & $\begin{array}{l}\text { Folha } \\
(100)\end{array}$ & $\begin{array}{l}\text { Herbácea } \\
\qquad(100)\end{array}$ & Fresca (100) & Infusão (100) & $\begin{array}{l}\text { Antimicrobiano (100), } \\
\text { combate início de } \\
\text { câncer (100) }\end{array}$ & $\begin{array}{l}\text { Atividade antimicrobiana (TRUITI et al., 2003), } \\
\text { anti-inflamatória e atividade contra Micrococcus } \\
\text { luteus, Escherichia coli e Bacillus subtilis } \\
\text { (SOUZA et al., 2004) }\end{array}$ \\
\hline $\begin{array}{l}\text { ASTERACEAE } \\
\text { Cynara scolymus L. } \\
\text { (alcachofra) }\end{array}$ & $\begin{array}{c}1 \\
(0,23)\end{array}$ & $\begin{array}{l}\text { Folha } \\
(100)\end{array}$ & $\begin{array}{l}\text { Herbácea } \\
\text { (100) }\end{array}$ & Fresca (100) & Infusão (100) & $\begin{array}{l}\text { Distúrbios } \\
\text { gastrintestinais (100) }\end{array}$ & $\begin{array}{l}\text { Antidispéptico (BRASIL, 2011; BRASIL, 2016), } \\
\text { diurético, antiflatulento, auxiliar na prevenção da } \\
\text { aterosclerose, além de atuar como coadjuvante } \\
\text { no tratamento de dislipidemia mista leve a } \\
\text { moderada e como auxiliar nos sintomas da } \\
\text { síndrome do intestino irritável (BRASIL, 2016) }\end{array}$ \\
\hline $\begin{array}{l}\text { ASTERACEAE } \\
\text { Matricaria chamomilla L. } \\
\text { (camomila, maçanilha) }\end{array}$ & $\begin{array}{c}6 \\
(1,41)\end{array}$ & Flor (100) & $\begin{array}{l}\text { Herbácea } \\
\text { (100) }\end{array}$ & $\begin{array}{l}\text { Seca }(50) \\
\text { fresca ou } \\
\text { seca }(33,33) \text {, } \\
\text { fresca } \\
(16,67)\end{array}$ & $\begin{array}{l}\text { Infusão (50), } \\
\text { decocção (50) }\end{array}$ & $\begin{array}{c}\text { Distúrbios } \\
\text { gastrintestinais }(66,67), \\
\text { calmante }(33,33), \\
\text { insônia }(33,33), \\
\text { doenças respiratórias } \\
(16,67) \text {, diurético } \\
(16,67) \text {, analgésico } \\
(16,67), \text { refrescante } \\
(16,67)\end{array}$ & $\begin{array}{l}\text { Antiespasmódico, ansiolítico e sedativo leve } \\
\text { para uso interno; anti-inflamatório em afecções } \\
\text { da cavidade bucal em uso externo (BRASIL, } \\
\text { 2011; BRASIL 2016). Seu extrato pode ter } \\
\text { potencial para fornecer substâncias com } \\
\text { atividade antibacteriana in vitro (CARVALHO et } \\
\text { al., 2014). O óleo essencial possui propriedades } \\
\text { espasmolíticas, antimicrobianas e desinfetantes } \\
\text { (HOMAMI et al., 2016) }\end{array}$ \\
\hline
\end{tabular}




\section{ASTERACEAE}

Mikania glomerata Spreng. (guaco)

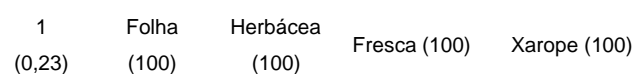

Doenças respiratórias

(100)

Algumas ações sobre as vias respiratórias foram

comprovadas experimentalmente e são justificadas pelos seus efeitos antialérgicos, broncodilatadores, antimicrobianos e antiedematogênicos. Outras atividades descritas na literatura são atividade antiinflamatória, antidiarreica (SOARES et al., 2006) e expectorante (BRASIL, 2011)

\section{ASTERACEAE}

Moquiniastrum (Less.) G. Sancho (cambará)

1 Folha Árvore Fresca ou

seca (100)
Infusão (100)
Doenças respiratórias (100), antitussígeno

(100)

As cascas do tronco possuem potencial para aplicação terapêutica em doenças causadas por bactérias Gram-positivas (STEFANELLO et al., 2006); as frações das cascas do tronco apresentaram elevada atividade antioxidante (STRAPASSON, 2014)

Analgésico $(33,33)$,

cicatrizante $(83,33)$,

anti-inflamatório (25)

\section{ASTERACEAE} Tanacetum vare L. 12 (palma fedida, catinga de $(2,82)$ mulata)

$$
\text { distúrbios }
$$

garganta $(8,33)$,
Maceração $(66,67)$, infusão $(16,67)$, decocção $(16,67)$ gastrintestinais $(16,67)$ vertigem $(8,33)$, reumatismo $(8,33)$, lesão bucal $(8,33)$

\begin{tabular}{|c|c|c|c|c|c|c|}
\hline $\begin{array}{l}\text { ASTERACEAE } \\
\text { Tithonia diversifolia (Hemsl.) } \\
\text { A. Gray } \\
\text { (dedo de deus, mão de deus) }\end{array}$ & $\begin{array}{c}3 \\
(0,94)\end{array}$ & $\begin{array}{l}\text { Folha } \\
(100)\end{array}$ & $\begin{array}{c}\text { Arbusto } \\
(66,67), \\
\text { herbácea } \\
(33,33)\end{array}$ & Fresca (100) & $\begin{array}{c}\text { Infusão }(66,67), \\
\text { decocção } \\
(33,33)\end{array}$ & Antidiabético (100) \\
\hline $\begin{array}{l}\text { BORAGINACEAE } \\
\text { Symphytum officinale L. } \\
\text { (confrei) }\end{array}$ & $\begin{array}{c}4 \\
(0,94)\end{array}$ & $\begin{array}{l}\text { Folha } \\
(100)\end{array}$ & $\begin{array}{c}\text { Herbácea } \\
\text { (100) }\end{array}$ & Fresca (100) & $\begin{array}{c}\text { Infusão (50), } \\
\text { decocção (25), } \\
\text { pomada (25) }\end{array}$ & $\begin{array}{c}\text { Cicatrizante (100), } \\
\text { doenças graves (25), } \\
\text { analgésico (25) }\end{array}$ \\
\hline $\begin{array}{l}\text { BRASSICACEAE } \\
\text { Brassica oleracea L. } \\
\text { (couve) }\end{array}$ & $\begin{array}{c}2 \\
(0,47)\end{array}$ & $\begin{array}{l}\text { Folha } \\
(100)\end{array}$ & $\begin{array}{c}\text { Herbácea } \\
\text { (100) }\end{array}$ & Fresca (100) & Sumo (100) & $\begin{array}{c}\text { Distúrbios } \\
\text { gastrintestinais (100) }\end{array}$ \\
\hline
\end{tabular}

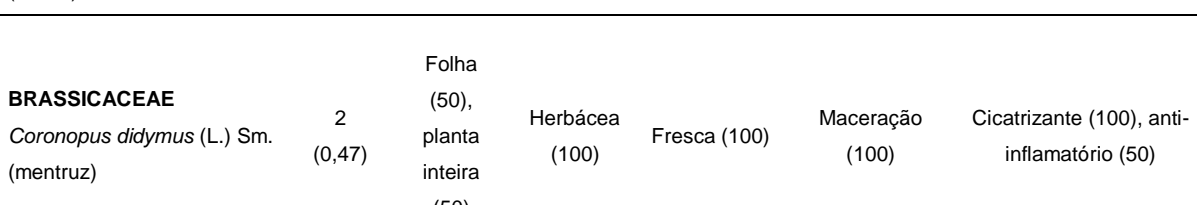

\begin{tabular}{|c|}
\hline $\begin{array}{l}\text { Atividade contra bactérias gram-positivas e } \\
\text { gram-negativas (HOLETZ et al., 2002); efeito } \\
\text { signifcante contra parasitas (LUIZE et al., 2005); } \\
\text { forte ação diurética (LAHLOU et al., 2007); } \\
\text { atividade anti-inflamatória, antioxidante, } \\
\text { antimalárica, vasorrelaxante, hipoglicemiante e } \\
\text { com efeito sobre úlcera gástrica (GUERREIRO } \\
\text { et al., 2016) }\end{array}$ \\
\hline $\begin{array}{l}\text { Possível atividade hipoglicêmica (DORNAS et } \\
\text { al., 2009), anti-inflamatória, antidiarreica, } \\
\text { antiamoébica e espasmolítica (LACERDA et al., } \\
\text { 2011) }\end{array}$ \\
\hline $\begin{array}{l}\text { Pomada possui ação cicatrizante, para } \\
\text { equimoses, hematomas e contusões (BRASIL, } \\
\text { 2011) }\end{array}$ \\
\hline $\begin{array}{l}\text { Possível atividade antioxidante (VRCHOVSKÁ } \\
\text { et al., 2006) }\end{array}$ \\
\hline $\begin{array}{l}\text { Infecções e problemas respiratórios (BADKE et } \\
\text { al., 2011); o extrato aquoso mostrou-se eficiente } \\
\text { no processo cicatricial de feridas cutâneas em } \\
\text { ratos Wistar, promovendo um aumento do número } \\
\text { de fibroblastos e fibras colágenas, provavelmente } \\
\text { devido à participação dos flavonóides, taninos e } \\
\text { saponinas (NITZ et al., 2006) }\end{array}$ \\
\hline
\end{tabular}
Infecções e problemas respiratórios (BADKE et al., 2011); o extrato aquoso mostrou-se eficiente no processo cicatricial de feridas cutâneas em ratos Wistar, promovendo um aumento do número de fibroblastos e fibras colágenas, provavelmente devido à participação dos flavonóides, taninos e saponinas (NITZ et al., 2006)

Apresenta ação contra úlcera gástrica e gastrite (ALMEIDA et al., 2015), e possivel atividade anti-inflamatória e antimicrobiana (SANTOSOLIVEIRA et al., 2009); estudos em ratos mostram que a espinheira santa foi eficiente na cura de úlceras induzidas por vários compostos, como indometacina, aspirina e reserpina (GRANDI, 2014); antidispéptico, antiácido e protetor da mucosa gástrica (BRASIL, 2016); efeito hipotensivo in vivo (CRESTANI et al., 2009)

\begin{tabular}{|c|c|c|c|c|c|c|c|}
\hline & \multirow[b]{2}{*}{$\begin{array}{c}\text { Planta } \\
\text { inteira } \\
(100)\end{array}$} & \multirow[b]{2}{*}{$\begin{array}{l}\text { Herbácea } \\
\text { (100) }\end{array}$} & & & & \multirow[b]{2}{*}{$\begin{array}{l}\text { Potencial analgésico (HASAN et al., 2010); } \\
\text { propriedade anti-reumática (SILVA et al., 2010) }\end{array}$} \\
\hline $\begin{array}{l}\text { COMMELINACEAE } \\
\text { Commelina cf. benghalensis } \\
\text { L. } \\
\text { (itapiava) }\end{array}$ & $\begin{array}{c}1 \\
(0,23)\end{array}$ & & & Fresca $(100)$ & Decocção (100) & Anti-inflamatório (100) & \\
\hline $\begin{array}{l}\text { CONVOLVULACE-AE } \\
\text { Ipomoea batatas (L.) Lam. } \\
\text { (batata doce) }\end{array}$ & $\begin{array}{c}2 \\
(0,47)\end{array}$ & $\begin{array}{l}\text { Folha e } \\
\text { caule }(50) \text {, } \\
\text { folha e } \\
\text { broto }(50)\end{array}$ & $\begin{array}{l}\text { Herbácea } \\
\text { (100) }\end{array}$ & Fresca $(100)$ & Infusão (100) & $\begin{array}{l}\text { Analgésico (100), anti- } \\
\text { inflamatório (50), } \\
\text { antimicrobiano (50) }\end{array}$ & $\begin{array}{l}\text { Anti-inflamatória (ASSIS, 2009), dor de dente e } \\
\text { inflamação gengival (GONÇALVES et al., 2014); } \\
\text { seus tubérculos têm atividade antimicrobiana e } \\
\text { antifúngica, sendo ativa contra C. albicans, } \\
\text { causadora de corrimentos vaginais e doenças } \\
\text { bucais (GRANDI, 2014) }\end{array}$ \\
\hline $\begin{array}{l}\text { CRASSULACEAE } \\
\text { Sedum spectabile Boreau } \\
\text { (bálsamo, bálsamo de jardim) }\end{array}$ & $\begin{array}{c}2 \\
(0,47)\end{array}$ & $\begin{array}{l}\text { Folha } \\
(100)\end{array}$ & $\begin{array}{c}\text { Herbácea } \\
\text { (100) }\end{array}$ & Fresca $(100)$ & In natura (100) & $\begin{array}{l}\text { Cicatrizante }(100), \\
\text { úlcera gástrica }(50)\end{array}$ & NC \\
\hline $\begin{array}{l}\text { CUCURBITACEAE } \\
\text { Sechium edule (Jacq.) Sw. } \\
\text { (chuchu) }\end{array}$ & $\begin{array}{c}3 \\
(0,70)\end{array}$ & $\begin{array}{c}\text { Folha } \\
(33,33), \\
\text { folha e } \\
\text { cipó } \\
(33,33), \\
\text { folha e } \\
\text { fruto } \\
(33,33)\end{array}$ & $\begin{array}{l}\text { Liana } \\
(100)\end{array}$ & Fresca $(100)$ & $\begin{array}{l}\text { Infusão }(66,67) \\
\text { decocção } \\
(33,33)\end{array}$ & Anti-hipertensivo (100) & Propriedade hipotensora (SOUZA et al., 2010) \\
\hline
\end{tabular}




\begin{tabular}{|c|c|c|c|c|c|c|c|}
\hline $\begin{array}{l}\text { EQUISETACEAE } \\
\text { Equisetum sp. } \\
\text { (cavalinha) }\end{array}$ & $\begin{array}{c}6 \\
(1,41)\end{array}$ & $\begin{array}{l}\text { Parte } \\
\text { aérea } \\
(100)\end{array}$ & $\begin{array}{l}\text { Herbácea } \\
\text { (100) }\end{array}$ & $\begin{array}{c}\text { Fresca ou } \\
\text { seca }(50) \\
\text { seca }(33,33) \text {, } \\
\text { fresca } \\
(16,67)\end{array}$ & Decocção (100) & $\begin{array}{l}\text { Distúrbios urinários } \\
(33,33), \text { distúrbios } \\
\text { renais }(33,33), \text { uso } \\
\text { geral }(16,67), \\
\text { antidiabético }(16,67) \text {, } \\
\text { evita trombose } \\
\quad(16,67), \text { anti- } \\
\text { inflamatório }(16,67)\end{array}$ & $\begin{array}{l}\text { Atividade diurética (MELLO, BUDEL, 2013; } \\
\text { BRASIL, 2016), antimicrobiana, hipoglicêmica, } \\
\text { antioxidante, anti-inflamatória, cicatrizante e } \\
\text { digestiva (MELLO; BUDEL, 2013). Efeito } \\
\text { antinoceptivo e anti-inflamatório foi observado } \\
\text { em ensaio farmacológico realizado em } \\
\text { camundongos, utilizando o extrato } \\
\text { hidroetanólico (BRASIL, 2016) }\end{array}$ \\
\hline $\begin{array}{l}\text { EUPHORBIACEAE } \\
\text { Euphorbia cotinifolia L. } \\
\text { (figueirinha roxa) }\end{array}$ & $\begin{array}{c}1 \\
(0,23)\end{array}$ & $\begin{array}{l}\text { Folha } \\
(100)\end{array}$ & $\begin{array}{l}\text { Arbusto } \\
(100)\end{array}$ & Fresca (100) & In natura (100) & Verrugas brancas $(100)$ & $\begin{array}{l}\text { Extratos hidroetanólicos apresentaram atividade } \\
\text { antimicrobiana e antioxidante (RIBEIRO, 2014) }\end{array}$ \\
\hline $\begin{array}{l}\text { EUPHORBIACEAE } \\
\text { Euphorbia umbellata (Pax) } \\
\text { Bruyns } \\
\text { (árvore de leite) }\end{array}$ & $\begin{array}{c}1 \\
(0,23)\end{array}$ & $\begin{array}{l}\text { Folha } \\
(100)\end{array}$ & $\begin{array}{c}\text { Árvore } \\
(100)\end{array}$ & Fresca (100) & In natura $(100)$ & Verrugas (100) & $\begin{array}{l}\text { O látex apresentou efeitos citotóxicos nas linhas } \\
\text { celulares tumorais, associadas com apoptose } \\
\text { (LUZ et al., 2015) }\end{array}$ \\
\hline $\begin{array}{l}\text { FABACEAE } \\
\text { Bauhinia forficata Link. } \\
\text { (pata de vaca árvore, pé de } \\
\text { boi) }\end{array}$ & $\begin{array}{c}3 \\
(0,70)\end{array}$ & $\begin{array}{c}\text { Folha } \\
(66,67), \\
\text { folha e } \\
\text { caule } \\
(33,33)\end{array}$ & $\begin{array}{c}\text { Árvore } \\
(100)\end{array}$ & $\begin{array}{c}\text { Fresca } \\
(66,67), \text { seca } \\
(33,33)\end{array}$ & $\begin{array}{c}\text { Decocção } \\
(66,67), \text { infusão } \\
(33,33)\end{array}$ & $\begin{array}{c}\text { Antidiabético }(66,67) \text {, } \\
\text { distúrbios renais } \\
(33,33) \text {, refrescante } \\
(33,33)\end{array}$ & $\begin{array}{l}\text { Efeito terapêutico hipoglicemiante potencial } \\
\text { para o tratamento do diabetes (ROSA et al., } \\
\text { 2012) }\end{array}$ \\
\hline $\begin{array}{l}\text { FABACEAE } \\
\text { Fabaceae sp1 } \\
\text { (café de gonzo) }\end{array}$ & $\begin{array}{c}1 \\
(0,23)\end{array}$ & $\begin{array}{c}\text { Planta } \\
\text { inteira } \\
(100)\end{array}$ & $\begin{array}{c}\text { Herbácea } \\
\text { (100) }\end{array}$ & Fresca $(100)$ & Infusão (100) & Tétano neonatal $(100)$ & NC \\
\hline $\begin{array}{l}\text { FABACEAE } \\
\text { Myrocarpus } \quad \text { frondosus } \\
\text { Allemão } \\
\text { (bálsamo de árvore, } \\
\text { cabreúva) }\end{array}$ & $\begin{array}{c}2 \\
(0,47)\end{array}$ & $\begin{array}{l}\text { Casca } \\
(100)\end{array}$ & $\begin{array}{c}\text { Árvore } \\
(100)\end{array}$ & $\begin{array}{l}\text { Fresca }(50) \\
\text { seca }(50)\end{array}$ & $\begin{array}{l}\text { Infusão (50), } \\
\text { decocção (50) }\end{array}$ & $\begin{array}{l}\text { Cicatrizante }(100), \\
\text { anti-inflamatório }(100)\end{array}$ & NC \\
\hline $\begin{array}{l}\text { FABACEAE } \\
\text { Phanera microstachya } \\
\text { (Raddi) L. P. Queiroz } \\
\text { (pata de vaca cipó) }\end{array}$ & $\begin{array}{c}1 \\
(0,23)\end{array}$ & $\begin{array}{l}\text { Folha e } \\
\text { caule / } \\
\text { cipó (100) }\end{array}$ & $\begin{array}{l}\text { Liana } \\
(100)\end{array}$ & $\begin{array}{l}\text { Fresca ou } \\
\text { seca }(100)\end{array}$ & Decocção (100) & Antidiabético (100) & NC \\
\hline $\begin{array}{l}\text { FABACEAE } \\
\text { Stryphnodendron } \\
\text { barbatimam Mart. } \\
\text { (barbatimão) }\end{array}$ & $\begin{array}{c}1 \\
(0,23)\end{array}$ & $\begin{array}{l}\text { Casca } \\
(100)\end{array}$ & $\begin{array}{l}\text { Árvore } \\
(100)\end{array}$ & Seca $(100)$ & Decocção (100) & Cicatrizante (100) & Cicatrizante (BRASIL, 2011; BRASIL, 2016) \\
\hline $\begin{array}{l}\text { GERANIACEAE } \\
\text { Pelargonium graveolens } \\
\text { L'Hér. ex Aiton } \\
\text { (malva cheirosa) }\end{array}$ & $\begin{array}{c}1 \\
(0,23)\end{array}$ & $\begin{array}{l}\text { Folha } \\
(100)\end{array}$ & $\begin{array}{c}\text { Arbusto } \\
(100)\end{array}$ & Fresca $(100)$ & Infusão (100) & Calmante (100) & $\begin{array}{l}\text { O óleo essencial apresentou atividade } \\
\text { antioxidante, potencial para tratamentos de } \\
\text { câncer (FAYED, 2009) e atividade antibacteriana } \\
\text { in vitro (HSOUNA; HAMDI, 2012; GHANNADI et } \\
\text { al., 2012) }\end{array}$ \\
\hline $\begin{array}{l}\text { HYPERICACEAE } \\
\text { Hypericum perforatum L. } \\
\text { (hipérico) }\end{array}$ & $\begin{array}{c}1 \\
(0,23)\end{array}$ & $\begin{array}{l}\text { Parte } \\
\text { aérea } \\
(100)\end{array}$ & $\begin{array}{c}\text { Herbácea } \\
\text { (100) }\end{array}$ & Fresca $(100)$ & Infusão (100) & Antidepressivo (100) & $\begin{array}{l}\text { Tratamento de estados depressivos leves a } \\
\text { moderados (WILIAMSON et al., 2012; BRASIL, } \\
\text { 2016), propriedades adstringentes para uso tópico } \\
\text { (WILLIAMSON et al. 2012) }\end{array}$ \\
\hline $\begin{array}{l}\text { JUGLANDACEAE } \\
\text { Juglans regia L. } \\
\text { (nogueira) }\end{array}$ & $\begin{array}{c}1 \\
(0,23)\end{array}$ & $\begin{array}{l}\text { Folha } \\
(100)\end{array}$ & $\begin{array}{c}\text { Árvore } \\
(100)\end{array}$ & Fresca (100) & Infusão (100) & $\begin{array}{l}\text { Cicatrizante }(100) \\
\text { depurativo (100) }\end{array}$ & $\begin{array}{l}\text { Possível atividade anti-inflamatória e } \\
\text { hipoglicemiante (NEGRELLE et al., 2007) }\end{array}$ \\
\hline $\begin{array}{l}\text { LAMIACEAE } \\
\text { Leonotis nepetifolia (L.) R. Br. } \\
\text { (cordão de frade) }\end{array}$ & $\begin{array}{c}1 \\
(0,23)\end{array}$ & $\begin{array}{l}\text { Folha } \\
(100)\end{array}$ & $\begin{array}{l}\text { Herbácea } \\
\text { (100) }\end{array}$ & Fresca $(100)$ & Infusão (100) & $\begin{array}{l}\text { Distúrbios urinários } \\
\qquad(100)\end{array}$ & $\begin{array}{l}\text { Possível atividade anti-inflamatória e } \\
\text { antimicrobiana (CRUZ et al., 2011) }\end{array}$ \\
\hline $\begin{array}{l}\text { LAMIACEAE } \\
\text { Leonurus sibiricus L. } \\
\text { (santos filhos, macaé, rubi) }\end{array}$ & $\begin{array}{c}2 \\
(0,47)\end{array}$ & $\begin{array}{l}\text { Parte } \\
\text { aérea } \\
(100)\end{array}$ & $\begin{array}{l}\text { Herbácea } \\
\text { (100) }\end{array}$ & Fresca $(100)$ & $\begin{array}{l}\text { Infusão (50), } \\
\text { maceração (50) }\end{array}$ & $\begin{array}{c}\text { Distúrbios } \\
\text { gastrintestinais }(100), \\
\text { analgésico }(50)\end{array}$ & $\begin{array}{l}\text { Efeito analgésico e atividade anti-inflamatória } \\
\text { significativa em ratos (ISLAM et al., 2005) }\end{array}$ \\
\hline $\begin{array}{l}\text { LAMIACEAE } \\
\text { Melissa officinalis L. } \\
\text { (erva cidreira, melissa) }\end{array}$ & $\begin{array}{c}21 \\
(4,93)\end{array}$ & $\begin{array}{l}\text { Folha } \\
(71,43) \\
\text { parte } \\
\text { aérea } \\
(28,57)\end{array}$ & $\begin{array}{l}\text { Herbácea } \\
(66,67), \\
\text { arbusto } \\
(33,33)\end{array}$ & Fresca $(100)$ & $\begin{array}{l}\text { Infusão }(80,95) \text {, } \\
\text { decocção } \\
(14,29) \\
\text { maceração } \\
(4,76)\end{array}$ & $\begin{array}{c}\text { Calmante }(85,71), \\
\text { distúrbios } \\
\text { cardiovasculares } \\
(19,05) \text {, doenças } \\
\text { respiratórias }(4,76) \text {, } \\
\text { antitussígeno }(4,76) \text {, } \\
\text { vertigem }(4,76) \text {, enjoo } \\
(4,76) \text {, fraqueza }(4,76) \text {, } \\
\text { recaída }(4,76)\end{array}$ & $\begin{array}{l}\text { Propriedade ansiolítica, antifúngica e } \\
\text { antibacteriana (COLUSSI et al., 2011); efeito } \\
\text { antiviral sobre lesões herpéticas tipo } 1 \text { verificado } \\
\text { em ensaio clínico (AMIN; OLIVA, 2014); atividade } \\
\text { antioxidativa, antibiótica, antibacteriana e sedativa } \\
\text { (LUZ et al., 2014); antiespasmódico, ansiolítico, } \\
\text { sedativo leve (BRASIL, 2011) }\end{array}$ \\
\hline
\end{tabular}




\begin{tabular}{|c|c|c|c|c|c|c|c|}
\hline $\begin{array}{l}\text { LAMIACEAE } \\
\text { Mentha arvensis L. } \\
\text { (hortelã, hortelã-pimenta, } \\
\text { menta, vick) }\end{array}$ & $\begin{array}{c}35 \\
(8,22)\end{array}$ & $\begin{array}{l}\text { Parte } \\
\text { aérea } \\
(54,29), \\
\text { folha } \\
(45,71)\end{array}$ & $\begin{array}{l}\text { Herbácea } \\
\text { (100) }\end{array}$ & Fresca (100) & $\begin{array}{c}\text { Infusão }(77,14) \text {, } \\
\text { decocção } \\
(11,43) \text {, sumo } \\
(8,57), \text { in natura } \\
(2,86)\end{array}$ & $\begin{array}{l}\text { Anti-helmíntico }(42,86) \text {, } \\
\text { calmante }(42,86), \\
\text { doenças respiratórias } \\
\text { (20), distúrbios } \\
\text { gastrintestinais }(14,29) \text {, } \\
\text { refrescante }(11,43), \\
\text { garganta }(8,57), \\
\text { antitussígeno }(5,71), \\
\text { antidepressivo }(5,71), \\
\text { anti-hipertensivo } \\
(2,86), \text { insônia }(2,86), \\
\text { distúrbios } \\
\text { cardiovasculares } \\
(2,86), \text { emagrecedor } \\
(2,86)\end{array}$ & $\begin{array}{l}\text { Seu óleo essencial é uma rica fonte de mentol, } \\
\text { que possui várias aplicações na indústria } \\
\text { farmacêutica, na perfumaria, em produtos de } \\
\text { higiene bucal, flavorizantes e aromatizantes } \\
\text { (CHAGAS et al., 2011); atividade expectorante } \\
\text { (COSTA; MAYWORM, 2011); a hortelã-pimenta } \\
\text { possui indicação como antidispéptico, } \\
\text { antiflatulento e antiespasmódico (BRASIL, } \\
\text { 2011); folhas de hortelã-pimenta e seu óleo } \\
\text { apresentam propriedades carminativas, } \\
\text { antiespasmódicas, diaforéticas e antissépticas, } \\
\text { sendo utilizadas principalmente no combate aos } \\
\text { sintomas de indigestão e comumente utilizada } \\
\text { como flavorizante em alimentos, cosméticos e } \\
\text { medicamentos (WILLIAMSON et al., 2012); } \\
\text { utilizada no combate de distúrbios estomacais, } \\
\text { do aparelho respiratório e de parasitas } \\
\text { intestinais (CHAGAS et al., 2013) }\end{array}$ \\
\hline $\begin{array}{l}\text { LAMIACEAE } \\
\text { Mentha pulegium L. } \\
\text { (poejo) }\end{array}$ & $\begin{array}{c}7 \\
(1,64)\end{array}$ & $\begin{array}{l}\text { Parte } \\
\text { aérea } \\
(100)\end{array}$ & $\begin{array}{l}\text { Herbácea } \\
\qquad(100)\end{array}$ & Fresca (100) & $\begin{array}{l}\text { Infusão }(85,71) \\
\text { decocção } \\
(14,29)\end{array}$ & $\begin{array}{c}\text { Doenças respiratórias } \\
(85,71) \text {, antitussígeno } \\
(28,57), \text { calmante } \\
(14,29)\end{array}$ & $\begin{array}{l}\text { Óleo essencial possui potente atividade } \\
\text { antimicrobiana (MAHBOUBI; HAGHI, 2008); } \\
\text { potencial ação antifúngica (FOGANHOLI et al., } \\
\text { 2015); efetiva ação antibacteriana, antifúngica e } \\
\text { acredita-se que tenha atividade carminativa e } \\
\text { diaforética (WILLIAMSON et al., 2012) }\end{array}$ \\
\hline $\begin{array}{l}\text { LAMIACEAE } \\
\text { Mentha spicata L. } \\
\text { (alevante, levante) }\end{array}$ & $\begin{array}{c}3 \\
(0,70)\end{array}$ & $\begin{array}{l}\text { Folha } \\
(66,67), \\
\text { planta } \\
\text { inteira } \\
(33,33)\end{array}$ & $\begin{array}{l}\text { Herbácea } \\
\qquad(100)\end{array}$ & Fresca (100) & Infusão (100) & $\begin{array}{l}\text { Antitussígeno }(66,67) \text {, } \\
\text { fortalece os nervos } \\
(33,33)\end{array}$ & $\begin{array}{l}\text { Tratamento de hipertensão arterial e age na } \\
\text { diminuição dos níveis de colesterol (RIBEIRO et } \\
\text { al., 2014) }\end{array}$ \\
\hline $\begin{array}{l}\text { LAMIACEAE } \\
\text { Ocimum carnosum (Spreng.) } \\
\text { Link \& Otto ex Benth. } \\
\text { (anis) }\end{array}$ & $\begin{array}{c}5 \\
(1,17)\end{array}$ & $\begin{array}{l}\text { Folha } \\
(60) \text {, folha } \\
\text { e semente } \\
(20) \\
\text { semente } \\
(20)\end{array}$ & $\begin{array}{l}\text { Arbusto } \\
(100)\end{array}$ & $\begin{array}{l}\text { Fresca }(80) \\
\text { seca }(20)\end{array}$ & Infusão (100) & $\begin{array}{l}\text { Calmante (40), anti- } \\
\text { hipertensivo (20), } \\
\text { distúrbios urinários } \\
\text { (20), distúrbios } \\
\text { gastrintestinais (20), } \\
\text { refrescante (40) }\end{array}$ & $\begin{array}{l}\text { Propriedades carminativas, antipiréticas e } \\
\text { antibacterianas (BHASIN, 2012) }\end{array}$ \\
\hline $\begin{array}{l}\text { LAMIACEAE } \\
\text { Origanum majorana L. } \\
\text { (manjerona) }\end{array}$ & $\begin{array}{c}3 \\
(0,70)\end{array}$ & $\begin{array}{c}\text { Parte } \\
\text { aérea } \\
(66,67), \\
\text { folha } \\
(33,37)\end{array}$ & $\begin{array}{l}\text { Herbácea } \\
\qquad(100)\end{array}$ & Fresca (100) & $\begin{array}{c}\text { Infusão }(33,33), \\
\text { decocção } \\
(33,33), \text { xarope } \\
(33,33)\end{array}$ & $\begin{array}{c}\text { Doenças respiratórias } \\
(33,33), \text { antitussígeno } \\
(33,33) \text {, antimicrobiano } \\
(33,33) \text {, enjoo }(33,33), \\
\text { abre o apetite }(33,33)\end{array}$ & $\begin{array}{l}\text { Possível atividade antibacteriana (JOSHI et al., } \\
\text { 2009) }\end{array}$ \\
\hline $\begin{array}{l}\text { LAMIACEAE } \\
\text { Plectranthus barbatus } \\
\text { Andrews } \\
\text { (boldo, falso boldo) }\end{array}$ & $\begin{array}{c}8 \\
(1,88)\end{array}$ & $\begin{array}{l}\text { Folha } \\
(100)\end{array}$ & $\begin{array}{l}\text { Herbácea } \\
\text { (100) }\end{array}$ & Fresca (100) & $\begin{array}{c}\text { Decocção } \\
(37,50), \\
\text { maceração } \\
(37,50), \text { infusão } \\
(25)\end{array}$ & $\begin{array}{c}\text { Distúrbios } \\
\text { gastrintestinais }(100), \\
\text { analgésico }(25), \\
\text { antidiabético }(12,50)\end{array}$ & $\begin{array}{l}\text { Condimentar, hipossecretora gástrica, controle } \\
\text { de gastrite, dispepsia, ressaca (SILVA et al., } \\
\text { 2009); antidispéptico (BRASIL, 2011), digestivo, } \\
\text { anti-hipertensivo e auxiliar na atividade } \\
\text { cardiovascular (BADKE et al., 2011) }\end{array}$ \\
\hline $\begin{array}{l}\text { LAMIACEAE } \\
\text { Plectranthus cf. neochilus } \\
\text { Schltr. } \\
\text { (boldo do chile) }\end{array}$ & $\begin{array}{c}2 \\
(0,47)\end{array}$ & $\begin{array}{l}\text { Folha } \\
(100)\end{array}$ & $\begin{array}{l}\text { Herbácea } \\
\qquad(100)\end{array}$ & Fresca (100) & $\begin{array}{l}\text { Maceração } \\
(100)\end{array}$ & $\begin{array}{c}\text { Distúrbios } \\
\text { gastrintestinais }(100) \\
\text { analgésico }(50)\end{array}$ & $\begin{array}{l}\text { A boldina, alcaloide constituinte das folhas do } \\
\text { boldo-do-chile, é um potente antioxidante } \\
\text { (WILLIAMSON et al., 2012). O boldo-do-chile é } \\
\text { indicado como antidispéptico, colagogo e } \\
\text { colerético (BRASIL, 2011; BRASIL, 2016) }\end{array}$ \\
\hline $\begin{array}{l}\text { LAMIACEAE } \\
\text { Rosmarinus officinalis L. } \\
\text { (alecrim, alecrim preto) }\end{array}$ & $\begin{array}{c}12 \\
(2,82)\end{array}$ & $\begin{array}{l}\text { Parte } \\
\text { aérea } \\
(100)\end{array}$ & $\begin{array}{c}\text { Arbusto } \\
(100)\end{array}$ & Fresca (100) & $\begin{array}{l}\text { Infusão }(66,67) \text {, } \\
\text { maceração } \\
(16,67), \\
\text { decocção } \\
(8,33), \text { in natura } \\
(8,33)\end{array}$ & $\begin{array}{l}\text { Calmante }(33,33) \text {, } \\
\text { analgésico }(16,67) \text {, } \\
\quad \text { distúrbios } \\
\text { cardiovasculares }(25) \text {, } \\
\text { diurético }(8,33) \text {, uso } \\
\quad \text { geral }(8,33)\end{array}$ & $\begin{array}{l}\text { Propriedade analgésica, espasmolítica, anti- } \\
\text { inflamatória, antifúngica (AMORIM, 1999; } \\
\text { ARRUDA, 2002); atividade antimicrobiana } \\
\text { contra bactérias Gram-positivas e Gram- } \\
\text { negativas, como Staphylococcus aureus, } \\
\text { Staphylococcus albus, Vibrio cholerae, } \\
\text { Escherichia coli, Lactobacillus brevis e } \\
\text { Pseudomonas fluorescens (ARRUDA, 2002); } \\
\text { potencial inibição do crescimento bacteriano em } \\
\text { estudo bacteriológico, com potencial utilização } \\
\text { no combate de bactérias cariogênicas, como } \\
\text { meio alternativo (ALVES et al., 2008); } \\
\text { hipotensor, colerético, protetor hepático (SILVA } \\
\text { et al., 2009); antidispéptico e anti-inflamatório } \\
\text { (BRASIL, 2011) }\end{array}$ \\
\hline $\begin{array}{l}\text { LAMIACEAE } \\
\text { Salvia hispanica L. } \\
\text { (chia) }\end{array}$ & $\begin{array}{c}1 \\
(0,23)\end{array}$ & $\begin{array}{l}\text { Semente } \\
(100)\end{array}$ & $\begin{array}{c}\text { Arbusto } \\
(100)\end{array}$ & Seca $(100)$ & $\begin{array}{c}\text { Maceração } \\
(100)\end{array}$ & Emagrecedor (100) & Contém antioxidantes (ALI et al., 2012) \\
\hline
\end{tabular}




\begin{tabular}{|c|c|c|c|c|c|c|c|}
\hline $\begin{array}{l}\text { LAMIACEAE } \\
\text { Salvia officinalis L. } \\
\text { (sálvia, salvinha, mãe do } \\
\text { corpo) }\end{array}$ & $\begin{array}{c}8 \\
(1,88)\end{array}$ & $\begin{array}{l}\text { Folha } \\
(100)\end{array}$ & $\begin{array}{l}\text { Herbácea } \\
\qquad(100)\end{array}$ & Fresca (100) & $\begin{array}{l}\text { Infusão }(62,50) \text {, } \\
\text { decocção }(25) \text {, } \\
\text { maceração } \\
(12,50)\end{array}$ & $\begin{array}{l}\text { Garganta }(87,50), \text { anti- } \\
\text { inflamatório }(50), \\
\text { cicatrizante }(12,50)\end{array}$ & $\begin{array}{l}\text { Ação antibacteriana sobre uma gama de } \\
\text { bactérias e leveduras (ZANIN et al., 2007); ação } \\
\text { antioxidante, antimicrobiana e hipoglicemiante } \\
\text { (FRANCISCO, 2010); antidispéptico em uso } \\
\text { interno, anti-inflamatório e antisséptico da } \\
\text { cavidade bucal em uso externo (BRASIL, 2011); } \\
\text { efeitos analgésicos e anti-inflamatórios (QNAIS } \\
\text { et al., 2010; MANSOURABADI et al., 2015); } \\
\text { apresenta propriedades antissépticas e } \\
\text { espasmolíticas; seus extratos apresentam } \\
\text { propriedades antioxidantes; o óleo pode ser } \\
\text { aplicado topicamente como antisséptico e } \\
\text { rubefaciente (WILLIAMSON et al., 2012) }\end{array}$ \\
\hline $\begin{array}{l}\text { LAMIACEAE } \\
\text { Tetradenia riparia (Hochst.) } \\
\text { Codd } \\
\text { (incenso) }\end{array}$ & $\begin{array}{c}1 \\
(0,23)\end{array}$ & $\begin{array}{l}\text { Parte } \\
\text { aérea } \\
(100)\end{array}$ & $\begin{array}{l}\text { Herbácea } \\
\text { (100) }\end{array}$ & Fresca $(100)$ & Infusão (100) & Analgésico (100) & $\begin{array}{l}\text { O extrato aquoso foliar mostrou efeito } \\
\text { antibacteriano para E. colie S. aureus em todas } \\
\text { as concentrações usadas, mostrando que a } \\
\text { planta apresenta potencial antibacteriano e } \\
\text { terapêutico (MARTINS et al., 2008); seu óleo } \\
\text { essencial apresentou boa atividade analgésica e } \\
\text { antimicrobiana (GAZIM et al., 2010) }\end{array}$ \\
\hline $\begin{array}{l}\text { LAURACEAE } \\
\text { Ocotea pretiosa (Nees \& } \\
\text { Mart.) Mez } \\
\text { (sassafrás) }\end{array}$ & $\begin{array}{c}1 \\
(0,23)\end{array}$ & $\begin{array}{l}\text { Casca } \\
(100)\end{array}$ & $\begin{array}{l}\text { Árvore } \\
(100)\end{array}$ & Fresca $(100$ & Infusão (100) & Reumatismo (100) & $\begin{array}{l}\text { Atividade antimicrobiana (SOUZA et al., 2004; } \\
\text { GONÇALVES et al., 2005) }\end{array}$ \\
\hline $\begin{array}{l}\text { LAURACEAE } \\
\text { Persea americana Mill. } \\
\text { (abacateiro) }\end{array}$ & $\begin{array}{c}3 \\
(0,70)\end{array}$ & $\begin{array}{l}\text { Folha } \\
(66,67) \\
\text { folha e } \\
\text { semente } \\
(33,33)\end{array}$ & $\begin{array}{l}\text { Árvore } \\
(100)\end{array}$ & Fresca (100) & $\begin{array}{l}\text { Decocção } \\
(66,67) \text {, } \\
\text { maceração } \\
(33,33)\end{array}$ & $\begin{array}{c}\text { Anti-hipertensivo } \\
(33,33) \text {, distúrbios } \\
\text { renais }(33,33), \\
\text { cicatrizante }(33,33), \\
\text { anti-inflamatório }(33,33)\end{array}$ & $\begin{array}{l}\text { O extrato apresentou efeito analgésico e anti- } \\
\text { inflamatório em ratos (ADEYEMI et al., 2002) }\end{array}$ \\
\hline $\begin{array}{l}\text { LAURACEAE } \\
\text { Persea major (Nees) L.E. } \\
\text { Kopp } \\
\text { (pau de andrade) }\end{array}$ & $\begin{array}{c}1 \\
(0,23)\end{array}$ & $\begin{array}{l}\text { Casca } \\
(100)\end{array}$ & $\begin{array}{l}\text { Árvore } \\
(100)\end{array}$ & Fresca (100) & Decocção (100) & Úlcera gástrica (100) & $\begin{array}{l}\text { Resultados obtidos após administração oral do } \\
\text { extrato hidroalcoólico bruto das cascas } \\
\text { sugeriram que esta planta possui uma ação } \\
\text { citoprotetora contra a lesão gástrica induzida } \\
\text { pelo etanol (COSMO et al., 2007); estudos } \\
\text { anteriores apresentaram atividade analgésica, } \\
\text { anti-edematogênica e gastroprotetora } \\
\text { (POTRICH et al., 2014) }\end{array}$ \\
\hline $\begin{array}{l}\text { LYTHRACEAE } \\
\text { Cuphea calophylla subsp. } \\
\text { mesostemon (Koehne) } \\
\text { Lourteig } \\
\text { (sete sangrias, erva de santa } \\
\text { luzia) }\end{array}$ & $\begin{array}{c}5 \\
(1,17)\end{array}$ & $\begin{array}{l}\text { Folha } \\
(60), \\
\text { planta } \\
\text { inteira } \\
(40)\end{array}$ & $\begin{array}{l}\text { Herbácea } \\
\qquad(100)\end{array}$ & Fresca (100) & $\begin{array}{l}\text { Decocção (60), } \\
\text { infusão (40) }\end{array}$ & $\begin{array}{l}\text { Hipocolesterolemiante } \\
\text { (40), antimicrobiano } \\
\text { (40), anti-hipertensivo } \\
\text { (20), distúrbios } \\
\text { gastrintestinais }(20), \\
\text { antiagregante } \\
\text { plaquetário }(20), \\
\text { refrescante }(20), \\
\text { analgésico }(20)\end{array}$ & $\begin{array}{l}\text { Espécies do gênero Cuphea, utilizadas na } \\
\text { medicina popular, são conhecidas por } \\
\text { prevenirem doenças cardiovasculares e por } \\
\text { serem eficazes contra hipertensão e } \\
\text { arteriosclerose (LUSA; BIASI, 2011) }\end{array}$ \\
\hline $\begin{array}{l}\text { LYTHRACEAE } \\
\text { Punica granatum L. } \\
\text { (romã) }\end{array}$ & $\begin{array}{c}5 \\
(1,17)\end{array}$ & $\begin{array}{l}\text { Casca do } \\
\text { fruto (40), } \\
\text { folha (20), } \\
\text { folha e } \\
\text { caule (20), } \\
\text { folha / } \\
\text { fruto / } \\
\text { semente } \\
(20)\end{array}$ & $\begin{array}{c}\text { Árvore } \\
(100)\end{array}$ & Fresca (100) & $\begin{array}{l}\text { Infusão (60), } \\
\text { decocção (40) }\end{array}$ & $\begin{array}{l}\text { Distúrbios } \\
\text { gastrintestinais (60), } \\
\text { antimicrobiano (40), } \\
\text { uso geral (20) }\end{array}$ & $\begin{array}{l}\text { Atividade antimicrobiana e anti-inflamatória } \\
\text { (WERKMAN et al., 2008); anti-inflamatório e } \\
\text { antisséptico da cavidade bucal (BRASIL, 2011) }\end{array}$ \\
\hline $\begin{array}{l}\text { MALVACEAE } \\
\text { Luehea divaricata Mart. } \\
\text { (açoita, soito) }\end{array}$ & $\begin{array}{c}1 \\
(0,23)\end{array}$ & $\begin{array}{l}\text { Folha } \\
(100)\end{array}$ & $\begin{array}{l}\text { Árvore } \\
(100)\end{array}$ & Fresca (100) & Infusão (100) & $\begin{array}{c}\text { Distúrbios } \\
\text { gastrintestinais }(100) \\
\text { emagrecedor }(100)\end{array}$ & NC \\
\hline $\begin{array}{l}\text { MALVACEAE } \\
\text { Malva parviflora L. } \\
\text { (malva) }\end{array}$ & $\begin{array}{c}2 \\
(0,47)\end{array}$ & $\begin{array}{l}\text { Folha } \\
(100)\end{array}$ & $\begin{array}{l}\text { Herbácea } \\
\text { (100) }\end{array}$ & Fresca (100) & Infusão (100) & $\begin{array}{l}\text { Anti-inflamatório (100), } \\
\text { analgésico (100) }\end{array}$ & $\begin{array}{l}\text { Ação antibiótica das sementes da malva e } \\
\text { atividade antifúngica (VASCONCELLOS et al., } \\
\text { 2011), anti-inflamatória e antioxidante } \\
\text { (HAEFFNER et al., 2012); propriedades anti- } \\
\text { inflamatórias, antimicrobianas e vêm sendo } \\
\text { testada no controle de crescimento de bactérias } \\
\text { presentes no biofilme dental (OLIVEIRA et al., } \\
\text { 2007; BUFFON et al., 2001); atividade anti- } \\
\text { inflamatória e efeito analgésico (AFOLAYAN et } \\
\text { al., 2010) }\end{array}$ \\
\hline
\end{tabular}




\begin{tabular}{|c|c|c|c|c|c|c|c|}
\hline $\begin{array}{l}\text { MALVACEAE } \\
\text { Malvastrum } \\
\text { coromandelianum (L.) } \\
\text { Garcke } \\
\text { (guanxuma) }\end{array}$ & $\begin{array}{c}2 \\
(0,47)\end{array}$ & $\begin{array}{l}\text { Raiz }(50) \text {, } \\
\text { planta } \\
\text { inteira } \\
(50)\end{array}$ & $\begin{array}{l}\text { Herbácea } \\
\text { (100) }\end{array}$ & Fresca (100) & $\begin{array}{l}\text { Infusão (50), } \\
\text { decocção (50) }\end{array}$ & $\begin{array}{l}\text { Queda de cabelo }(50) \\
\text { antimicrobiano }(50)\end{array}$ & NC \\
\hline $\begin{array}{l}\text { MORACEAE } \\
\text { Ficus carica L. } \\
\text { (figo) }\end{array}$ & $\begin{array}{c}1 \\
(0,23)\end{array}$ & $\begin{array}{l}\text { Folha } \\
(100)\end{array}$ & $\begin{array}{l}\text { Árvore } \\
(100)\end{array}$ & Fresca (100) & Infusão (100) & $\begin{array}{l}\text { Antitussígeno }(100) \\
\text { garganta }(100)\end{array}$ & $\begin{array}{l}\text { Atividade imunoestimulante e anti-cancerígena } \\
\text { (NEGRELLE et al., 2007) }\end{array}$ \\
\hline $\begin{array}{l}\text { MORACEAE } \\
\text { Morus cf. alba L. } \\
\text { (amoreira) }\end{array}$ & $\begin{array}{c}2 \\
(0,47)\end{array}$ & $\begin{array}{l}\text { Folha } \\
(50) \text {, folha } \\
\text { e caule } \\
(50)\end{array}$ & $\begin{array}{c}\text { Árvore } \\
(100)\end{array}$ & Fresca $(100)$ & Infusão (100) & $\begin{array}{l}\text { Hipocolesterolemiant } \\
\text { e (100), diurético }(50)\end{array}$ & $\begin{array}{l}\text { Significativo efeito anti-inflamatório (PEREIRA } \\
\text { et al., 2013); alguns compostos fenólicos } \\
\text { apresentam potencial antioxidante (OLIVEIRA } \\
\text { et al., 2013) }\end{array}$ \\
\hline $\begin{array}{l}\text { MORACEAE } \\
\text { Sorocea bonplandii (Baill.) } \\
\text { W.C. Burger, Lanj. \& Wess. } \\
\text { Boer } \\
\text { (espinheira santa) }\end{array}$ & $\begin{array}{c}1 \\
(0,23)\end{array}$ & $\begin{array}{l}\text { Folha } \\
(100)\end{array}$ & $\begin{array}{l}\text { Árvore } \\
(100)\end{array}$ & Fresca (100) & Decocção (100) & Distúrbios renais (100) & $\begin{array}{l}\text { Atividade anticoagulante in vitro (PEREIRA, } \\
\text { 2005); ação analgésica e anti-ulcerogênica } \\
\text { semelhante à da M. ilicifolia (SANTOS- } \\
\text { OLIVEIRA et al., 2009) }\end{array}$ \\
\hline $\begin{array}{l}\text { MYRTACEAE } \\
\text { Eucalyptus grandis W. Hill } \\
\text { (eucalipto) }\end{array}$ & $\begin{array}{c}4 \\
(0,94)\end{array}$ & $\begin{array}{l}\text { Folha } \\
(100)\end{array}$ & $\begin{array}{l}\text { Árvore } \\
(100)\end{array}$ & Fresca (100) & $\begin{array}{l}\text { Infusão (50), } \\
\text { decocção (25), } \\
\text { maceração (25) }\end{array}$ & $\begin{array}{l}\text { Doenças respiratórias } \\
\qquad(100)\end{array}$ & $\begin{array}{l}\text { Extratos de óleo essencial de algumas espécies } \\
\text { possuem efeitos analgésicos centrais e } \\
\text { periféricos, além de atividades anti-inflamatórias } \\
\text { (SILVA et al., 2003) }\end{array}$ \\
\hline $\begin{array}{l}\text { MYRTACEAE } \\
\text { Eugenia involucrata DC. } \\
\text { (cereja) }\end{array}$ & $\begin{array}{c}1 \\
(0,23)\end{array}$ & $\begin{array}{l}\text { Folha } \\
(100)\end{array}$ & $\begin{array}{c}\text { Árvore } \\
(100)\end{array}$ & Fresca $(100)$ & Infusão (100) & Ácido úrico (100) & $\begin{array}{l}\text { Ação antidiarreica e digestiva (QUEIROZ et al., } \\
\text { 2015) }\end{array}$ \\
\hline $\begin{array}{l}\text { MYRTACEAE } \\
\text { Eugenia uniflora L. } \\
\text { (pitanga preta, pitangueira) }\end{array}$ & $\begin{array}{c}2 \\
(0,47)\end{array}$ & $\begin{array}{l}\text { Folha e } \\
\text { casca } \\
(100)\end{array}$ & $\begin{array}{c}\text { Árvore } \\
(100)\end{array}$ & Fresca (100) & $\begin{array}{l}\text { Infusão (50), } \\
\text { decocção (50) }\end{array}$ & $\begin{array}{l}\text { Distúrbios } \\
\text { gastrintestinais (50), } \\
\text { emagrecedor (50), } \\
\text { analgésico (50), } \\
\text { antipirético (50) }\end{array}$ & $\begin{array}{l}\text { Ação antioxidante e antimicrobiana (MILANESI } \\
\text { et al., 2009; OLIVEIRA et al., 2011) in vitro } \\
\text { (AURICCHIO et al., 2007), possui atividade } \\
\text { contra Streptococcus, Escherichia colie Bacillus } \\
\text { cereus, além de resistência a Pseudomonas } \\
\text { aeruginosa (MILANESI et al., 2009) }\end{array}$ \\
\hline $\begin{array}{l}\text { MYRTACEAE } \\
\text { Myrcia sphaerocarpa DC. } \\
\text { (pedra ume caa) }\end{array}$ & $\begin{array}{c}1 \\
(0,23)\end{array}$ & $\begin{array}{l}\text { Folha } \\
(100)\end{array}$ & $\begin{array}{c}\text { Árvore } \\
(100)\end{array}$ & Seca $(100)$ & Decocção (100) & Antidiabético (100) & $\begin{array}{l}\text { Efeito terapêutico hipoglicemiante potencial } \\
\text { para o tratamento do diabetes (ROSA et al., } \\
\text { 2012) }\end{array}$ \\
\hline $\begin{array}{l}\text { MYRTACEAE } \\
\text { Plinia cauliflora (DC.) Kausel } \\
\text { (jabuticaba) }\end{array}$ & $\begin{array}{c}3 \\
(0,70)\end{array}$ & $\begin{array}{l}\text { Casca do } \\
\text { fruto }(100)\end{array}$ & $\begin{array}{l}\text { Árvore } \\
(100)\end{array}$ & Seca $(100)$ & $\begin{array}{c}\text { Maceração } \\
(66,67), \text { infusão } \\
(33,33)\end{array}$ & $\begin{array}{c}\text { Distúrbios } \\
\text { gastrintestinais }(66,67), \\
\text { anti-inflamatório } \\
(33,33), \text { cicatrizante } \\
(33,33)\end{array}$ & $\begin{array}{l}\text { Atividades antioxidantes e antimicrobianas } \\
\text { (SOUZA-MOREIRA et al., 2010); atividade } \\
\text { antifúngica (MACHADO, 2015) }\end{array}$ \\
\hline $\begin{array}{l}\text { MYRTACEAE } \\
\text { Psidium cattleyanum Sabine } \\
\text { (araçá amarelo) }\end{array}$ & $\begin{array}{c}2 \\
(0,47)\end{array}$ & $\begin{array}{c}\text { Folha } \\
(50) \\
\text { casca }(50)\end{array}$ & $\begin{array}{l}\text { Árvore } \\
(100)\end{array}$ & Fresca (100) & Decocção (100) & $\begin{array}{c}\text { Distúrbios } \\
\text { gastrintestinais }(100)\end{array}$ & NC \\
\hline $\begin{array}{l}\text { MYRTACEAE } \\
\text { Psidium guajava L. } \\
\text { (goiabeira, goiaba vermelha) }\end{array}$ & $\begin{array}{c}6 \\
(1,41)\end{array}$ & $\begin{array}{l}\text { Folha } \\
(66,67) \\
\text { folha e } \\
\text { casca } \\
(16,67) \\
\text { folha e } \\
\text { broto } \\
(16,67)\end{array}$ & $\begin{array}{c}\text { Árvore } \\
(100)\end{array}$ & Fresca (100) & $\begin{array}{l}\text { Infusão (50), } \\
\text { decocção (50) }\end{array}$ & $\begin{array}{c}\text { Distúrbios } \\
\text { gastrintestinais }(83,33), \\
\text { lesão bucal }(50), \\
\text { inflamação bucal } \\
(33,33) \text {, aftas }(33,33), \\
\text { anti-inflamatório } \\
(16,67), \text { garganta } \\
(16,67), \text { analgésico } \\
(16,67)\end{array}$ & $\begin{array}{l}\text { Efeito antidiarréico, antipirético e anti- } \\
\text { inflamatório, ação antiespasmódica } \\
\text { (VENDRUSCOLO et al., 2005); atividade } \\
\text { antimicrobiana, antifúngica e antitussígena } \\
\text { (ALVES et al., 2009); no tratamento da diarreia } \\
\text { aguda não infecciosa e enterite por rotavirus } \\
\text { (BRASIL, 2016); efeitos contra radicais livres, } \\
\text { cardiotônicos, analgésico, sedativo (ALMEIDA } \\
\text { et al., 2006) }\end{array}$ \\
\hline $\begin{array}{l}\text { MYRTACEAE } \\
\text { Psidium longipetiolatum D. } \\
\text { Legrand } \\
\text { (araçá vermelho) }\end{array}$ & $\begin{array}{c}1 \\
(0,23)\end{array}$ & $\begin{array}{l}\text { Folha } \\
(100)\end{array}$ & $\begin{array}{l}\text { Árvore } \\
(100)\end{array}$ & Fresca $(100)$ & Infusão (100) & Anti-inflamatório (100) & NC \\
\hline $\begin{array}{l}\text { PAPAVERACEAE } \\
\text { Chelidonium majus L. } \\
\text { (jaguarandi, nervo ciático) }\end{array}$ & $\begin{array}{c}2 \\
(0,47)\end{array}$ & $\begin{array}{c}\text { Folha } \\
\text { (50), parte } \\
\text { aérea (50) }\end{array}$ & $\begin{array}{c}\text { Herbácea } \\
\text { (100) }\end{array}$ & Fresca (100) & $\begin{array}{l}\text { Decocção (50), } \\
\text { maceração (50) }\end{array}$ & $\begin{array}{l}\text { Distúrbios renais }(50) \\
\text { analgésico }(50)\end{array}$ & $\begin{array}{l}\text { Utilizada na medicina chinesa como } \\
\text { antitussígeno, anti-inflamatório e desintoxicante } \\
\text { (WILLIAMSON et al., 2012) }\end{array}$ \\
\hline $\begin{array}{l}\text { PASSIFLORACEAE } \\
\text { Passiflora edulis Sims } \\
\text { (maracujá) }\end{array}$ & $\begin{array}{c}1 \\
(0,23)\end{array}$ & $\begin{array}{l}\text { Folha } \\
(100)\end{array}$ & $\begin{array}{c}\text { Árvore } \\
(100)\end{array}$ & Fresca $(100)$ & Infusão (100) & Calmante (100) & $\begin{array}{l}\text { Efeitos sedativos e ansiolíticos (VEIGA JUNIOR } \\
\text { et al., 2005; SILVEIRA et al., 2008; BRASIL, } \\
\text { 2011; WILLIAMSON et al., 2012; BRASIL, 2016) }\end{array}$ \\
\hline $\begin{array}{l}\text { PETIVERIACEAE } \\
\text { Petiveria alliacea L. } \\
\text { (guiné) }\end{array}$ & $\begin{array}{c}9 \\
(2,11)\end{array}$ & $\begin{array}{l}\text { Parte } \\
\text { aérea } \\
(100)\end{array}$ & $\begin{array}{c}\text { Herbácea } \\
\text { (100) }\end{array}$ & $\begin{array}{l}\text { Fresca } \\
(88,89), \\
\text { fresca ou } \\
\text { seca }(11,11)\end{array}$ & $\begin{array}{c}\text { Infusão }(66,67), \\
\text { decocção } \\
(11,11), \\
\text { maceração } \\
(11,11), \\
\text { defumação } \\
(11,11)\end{array}$ & $\begin{array}{c}\text { Calmante }(55,56), \\
\text { defumação }(33,33) \text {, } \\
\text { distúrbios } \\
\text { cardiovasculares } \\
(11,11), \text { refrescante } \\
(11,11)\end{array}$ & $\begin{array}{l}\text { Raízes e folhas têm sido utilizadas na medicina } \\
\text { popular por suas ações antiespasmódicas, } \\
\text { sedativas, diuréticas e anti-helmínticas. O } \\
\text { extrato da raiz mostrou efeito analgésico } \\
\text { significativo no modelo experimental utilizado } \\
\text { (LOPES-MARTINS et al., 2002) }\end{array}$ \\
\hline
\end{tabular}




\begin{tabular}{|c|c|c|c|c|c|c|c|}
\hline $\begin{array}{l}\text { PHYLLANTHACE-AE } \\
\text { Phyllanthus niruri L. } \\
\text { (quebra pedra) }\end{array}$ & $\begin{array}{c}6 \\
(1,41)\end{array}$ & $\begin{array}{c}\text { Planta } \\
\text { inteira } \\
(66,67), \\
\text { parte } \\
\text { aérea } \\
(33,33)\end{array}$ & $\begin{array}{l}\text { Herbácea } \\
\text { (100) }\end{array}$ & $\begin{array}{c}\text { Fresca } \\
(83,33), \text { seca } \\
(16,67)\end{array}$ & $\begin{array}{c}\text { Decocção } \\
(66,67), \text { infusão } \\
(33,33)\end{array}$ & $\begin{array}{l}\text { Distúrbios renais }(100) \text {, } \\
\text { antidiabético }(16,67)\end{array}$ & $\begin{array}{l}\text { Atividade comprovada no tratamento da } \\
\text { urolitíase, dados experimentais sugerem efeitos } \\
\text { que promovem a eliminação de cálculos renais, } \\
\text { potencial para interferir na patogênese da } \\
\text { urolitíase, propriedades analgésicas e atividade } \\
\text { antiespasmódica (MARQUES, 2010); litolítico } \\
\text { nos casos de litíase urinária (BRASIL, 2011; } \\
\text { CARDOSO et al., 2009), auxiliar nas cistites } \\
\text { (CARDOSO et al., 2009). A tintura também } \\
\text { possui indicação diurética (BRASIL, 2011); } \\
\text { eficaz na prevenção dos urólitos (CRUCES et } \\
\text { al., 2013) }\end{array}$ \\
\hline $\begin{array}{l}\text { PIPERACEAE } \\
\text { Piper amalago L. } \\
\text { (jaborandi) }\end{array}$ & $\begin{array}{c}1 \\
(0,23)\end{array}$ & $\begin{array}{l}\text { Folha } \\
(100)\end{array}$ & $\begin{array}{l}\text { Herbácea } \\
\text { (100) }\end{array}$ & Fresca (100) & Infusão (100) & $\begin{array}{l}\text { Anti-inflamatório (100), } \\
\text { analgésico (100), } \\
\text { antimicrobiano (100), } \\
\text { doenças respiratórias } \\
(100)\end{array}$ & $\begin{array}{l}\text { Possível efeito anti-inflamatório (SOSA et al., } \\
\text { 2002); potencial atividade anti-inflamatória e } \\
\text { antimicrobiana (ROVANI et al., 2013) }\end{array}$ \\
\hline $\begin{array}{l}\text { PLANTAGINACEAE } \\
\text { Plantago major L. } \\
\text { (tanchagem, } \\
\text { tanchaz da horta) }\end{array}$ & $\begin{array}{c}10 \\
(2,35)\end{array}$ & $\begin{array}{l}\text { Folha } \\
(70), \\
\text { planta } \\
\text { inteira } \\
(30)\end{array}$ & $\begin{array}{l}\text { Herbácea } \\
\text { (100) }\end{array}$ & $\begin{array}{l}\text { Fresca }(90) \\
\text { fresca ou } \\
\text { seca }(10)\end{array}$ & $\begin{array}{l}\text { Infusão (60), } \\
\text { decocção (30), } \\
\text { maceração (10) }\end{array}$ & $\begin{array}{l}\text { Antimicrobiano (70), } \\
\text { anti-inflamatório (50), } \\
\text { garganta (40), } \\
\text { analgésico (40), lesão } \\
\text { bucal (20), distúrbios } \\
\text { urinários (10), doenças } \\
\text { respiratórias (10), } \\
\text { cicatrizante (10), aftas } \\
(10)\end{array}$ & $\begin{array}{l}\text { Ação antimicrobiana (CAVALCANTE, 2010), } \\
\text { anti-inflamatória e antisséptica da cavidade } \\
\text { bucal (BRASIL, 2011); extrato possui ação } \\
\text { adstringente, cicatrizante, antimicrobiana e anti- } \\
\text { inflamatória (BUFFON et al., 2001); extrato } \\
\text { aquoso possui atividades anti-inflamatórias e } \\
\text { analgésicas (GUILLÉN et al., 1997) }\end{array}$ \\
\hline $\begin{array}{l}\text { POACEAE } \\
\text { Coix lacryma-jobi L. } \\
\text { (rosário) }\end{array}$ & $\begin{array}{c}4 \\
(0,94)\end{array}$ & $\begin{array}{c}\text { Parte } \\
\text { aérea } \\
(50), \text { folha } \\
(25), \text { folha } \\
\text { e fruto } \\
(25)\end{array}$ & $\begin{array}{l}\text { Herbácea } \\
\qquad(100)\end{array}$ & $\begin{array}{l}\text { Fresca }(50) \\
\text { fresca ou } \\
\text { seca }(50)\end{array}$ & Infusão (100) & $\begin{array}{l}\text { Calmante (50), } \\
\text { refrescante (50), anti- } \\
\text { inflamatório (25), } \\
\text { distúrbios urinários } \\
\text { (25), defumação }(25)\end{array}$ & $\begin{array}{l}\text { Os frutos são utilizados no tratamento de } \\
\text { inflamações (CAMPELO, 1988) }\end{array}$ \\
\hline $\begin{array}{l}\text { POACEAE } \\
\text { Cymbopogon citratus (DC.) } \\
\text { Stapf } \\
\text { (capim-limão) }\end{array}$ & $\begin{array}{c}11 \\
(2,58)\end{array}$ & $\begin{array}{l}\text { Folha } \\
(100)\end{array}$ & $\begin{array}{l}\text { Herbácea } \\
\qquad(100)\end{array}$ & Fresca (100) & $\begin{array}{c}\text { Decocção } \\
(72,73), \text { infusão } \\
(27,27)\end{array}$ & $\begin{array}{c}\text { Calmante }(81,82), \\
\text { doenças respiratórias } \\
(9,09) \text {, anti- } \\
\text { hipertensivo }(9,09) \text {, } \\
\text { refrescante }(9,09)\end{array}$ & $\begin{array}{l}\text { Calmante, espasmolítico (SILVA et al., 2009), } \\
\text { antiespasmódico, ansiolítico e sedativo leve } \\
\text { (BRASIL, 2011) }\end{array}$ \\
\hline $\begin{array}{l}\text { POACEAE } \\
\text { Zea mays L. } \\
\text { (cabelo do milho) }\end{array}$ & $\begin{array}{c}1 \\
(0,23)\end{array}$ & $\begin{array}{l}\text { Estigma } \\
(100)\end{array}$ & $\begin{array}{l}\text { Herbácea } \\
\text { (100) }\end{array}$ & Seca (100) & Decocção (100) & $\begin{array}{l}\text { Distúrbios urinários } \\
\qquad(100)\end{array}$ & NC \\
\hline $\begin{array}{l}\text { POLYPODIACEAE } \\
\text { Microgramma vacciniifolia } \\
\text { (Langsd. \& Fisch.) Copel. } \\
\text { (solda osso, soldinha) }\end{array}$ & $\begin{array}{c}1 \\
(0,23)\end{array}$ & $\begin{array}{l}\text { Parte } \\
\text { aérea } \\
(100)\end{array}$ & $\begin{array}{l}\text { Herbácea } \\
\qquad(100)\end{array}$ & Fresca (100) & Decocção (100) & $\begin{array}{l}\text { Cicatrizante dos } \\
\text { ossos }(100)\end{array}$ & NC \\
\hline $\begin{array}{l}\text { ROSACEAE } \\
\text { Eriobotrya japonica (Thunb.) } \\
\text { Lindl. } \\
\text { (ameixa amarela) }\end{array}$ & $\begin{array}{c}2 \\
(0,47)\end{array}$ & $\begin{array}{l}\text { Folha } \\
(100)\end{array}$ & $\begin{array}{c}\text { Árvore } \\
(100)\end{array}$ & Fresca (100) & $\begin{array}{l}\text { Infusão (50), } \\
\text { decocção (50) }\end{array}$ & $\begin{array}{l}\text { Anti-hipertensivo }(50) \text {, } \\
\text { laxante }(50), \text { banho de } \\
\text { assento }(50)\end{array}$ & $\begin{array}{l}\text { Efeitos hipoglicemiante, estomático e no } \\
\text { tratamento de doenças de pele (SILVA et al., } \\
2015 \text { ) }\end{array}$ \\
\hline $\begin{array}{l}\text { ROSACEAE } \\
\text { Prunus salicina Lindl. } \\
\text { (ameixa preta) }\end{array}$ & $\begin{array}{c}2 \\
(0,47)\end{array}$ & $\begin{array}{l}\text { Folha e } \\
\text { fruto }(50), \\
\text { broto }(50)\end{array}$ & $\begin{array}{c}\text { Árvore } \\
(100)\end{array}$ & Fresca (100) & Infusão (100) & $\begin{array}{c}\text { Distúrbios } \\
\text { gastrintestinais }(50), \\
\text { doenças respiratórias } \\
(50)\end{array}$ & NC \\
\hline $\begin{array}{l}\text { ROSACEAE } \\
\text { Pyrus communis L. } \\
\text { (pêra) }\end{array}$ & $\begin{array}{c}1 \\
(0,23)\end{array}$ & $\begin{array}{l}\text { Folha } \\
(100)\end{array}$ & $\begin{array}{c}\text { Árvore } \\
(100)\end{array}$ & Fresca $(100)$ & Decocção (100) & $\begin{array}{c}\text { Anti-hipertensivo } \\
(100)\end{array}$ & NC \\
\hline $\begin{array}{l}\text { RUTACEAE } \\
\text { Citrus aurantifolia Swingle } \\
\text { (limão) }\end{array}$ & $\begin{array}{c}2 \\
(0,47)\end{array}$ & $\begin{array}{l}\text { Fruto }(50), \\
\text { casca do } \\
\text { fruto }(50)\end{array}$ & $\begin{array}{c}\text { Árvore } \\
(100)\end{array}$ & $\begin{array}{l}\text { Fresca }(50) \\
\text { seca }(50)\end{array}$ & $\begin{array}{c}\text { Maceração } \\
(50), \text { sumo (50) }\end{array}$ & $\begin{array}{c}\text { Antidiabético }(50) \text {, } \\
\text { hipocolesterolemiante } \\
(50)\end{array}$ & $\begin{array}{l}\text { Antioxidante, devido à vitamina C, aos } \\
\text { flavonoides e pectinas (VENDRUSCOLO et al., } \\
\text { 2005) }\end{array}$ \\
\hline $\begin{array}{l}\text { RUTACEAE } \\
\text { Citrus reticulata Blanco } \\
\text { (mexiriqueira, mimoseira) }\end{array}$ & $\begin{array}{c}3 \\
(0,70)\end{array}$ & $\begin{array}{l}\text { Folha } \\
(100)\end{array}$ & $\begin{array}{c}\text { Árvore } \\
(100)\end{array}$ & $\begin{array}{c}\text { Fresca } \\
(66,67), \\
\text { fresca ou } \\
\text { seca }(33,33)\end{array}$ & Infusão (100) & $\begin{array}{c}\text { Calmante }(66,67) \text {, } \\
\text { labirintite }(66,67), \\
\text { antidepressivo }(33,33)\end{array}$ & $\begin{array}{l}\text { Pode induzir apoptose em células de câncer } \\
\text { gástrico humano (KIM et al., 2005); atividade } \\
\text { antioxidante (ZHANG et al., 2014) }\end{array}$ \\
\hline $\begin{array}{l}\text { RUTACEAE } \\
\text { Citrus } \times \text { aurantiifolia Christm.) } \\
\text { Swingle } \\
\text { (lima) }\end{array}$ & $\begin{array}{c}1 \\
(0,23)\end{array}$ & $\begin{array}{c}\text { Folha e } \\
\text { fruto }(100)\end{array}$ & $\begin{array}{c}\text { Árvore } \\
(100)\end{array}$ & Fresca (100) & Infusão (100) & $\begin{array}{l}\text { Anti-hipertensivo } \\
\text { (100), distúrbios renais } \\
\text { (100) }\end{array}$ & Antimicrobiana (ARIAS; RAMÓN-LACA, 2005) \\
\hline
\end{tabular}




\begin{tabular}{|c|c|c|c|c|c|c|c|}
\hline $\begin{array}{l}\text { RUTACEAE } \\
\text { Citrus } \times \text { sinensis (L.) Osbeck } \\
\text { (laranjeira comum, laranja } \\
\text { lima) }\end{array}$ & $\begin{array}{c}5 \\
(1,17)\end{array}$ & $\begin{array}{l}\text { Folha } \\
(60) \text {, folha } \\
\text { e fruto } \\
(20) \text {, folha } \\
\text { e casca } \\
\text { do fruto } \\
\text { (20) }\end{array}$ & $\begin{array}{c}\text { Árvore } \\
(100)\end{array}$ & Fresca (100) & $\begin{array}{l}\text { Decocção (60), } \\
\text { infusão (40) }\end{array}$ & $\begin{array}{l}\text { Doenças respiratórias } \\
\text { (60), antitussígeno (40), } \\
\text { antimicrobiano (20), } \\
\text { anti-hipertensivo (20) }\end{array}$ & $\begin{array}{l}\text { Anorexia e dispepsias (casca do fruto) } \\
\text { (VENDRUSCOLO et al., 2005); atividade } \\
\text { antimicrobiana (PRUDENTE; MOURA, 2013) }\end{array}$ \\
\hline $\begin{array}{l}\text { RUTACEAE } \\
\text { Ruta graveolens L. } \\
\text { (arruda) }\end{array}$ & $\begin{array}{c}15 \\
(3,52)\end{array}$ & $\begin{array}{l}\text { Parte } \\
\text { aérea } \\
(100)\end{array}$ & $\begin{array}{l}\text { Arbusto } \\
(100)\end{array}$ & $\begin{array}{c}\text { Fresca } \\
(93,33) \\
\text { fresca ou } \\
\text { seca }(6,67)\end{array}$ & $\begin{array}{l}\text { Infusão (40), } \\
\text { maceração } \\
(40), \text { in natura } \\
(13,33), \text { xarope } \\
(6,67)\end{array}$ & $\begin{array}{l}\text { Anti-inflamatório }(60) \text {, } \\
\text { recaída }(33,33), \\
\text { analgésico }(33,33) \text {, } \\
\text { calmante }(6,67), \\
\text { refrescante }(6,67) \text {, } \\
\text { defumação }(6,67)\end{array}$ & $\begin{array}{l}\text { Ação anti-inflamatória (BORCARD et al., 2015), } \\
\text { antihelmíntica, febrífuga, emenagoga (SILVA et } \\
\text { al., 2009) }\end{array}$ \\
\hline $\begin{array}{l}\text { SIMAROUBACEAE } \\
\text { Picrasma crenata Engl. in } \\
\text { Engl. \& Prantl } \\
\text { (pau de raposa) }\end{array}$ & $\begin{array}{c}2 \\
(0,47)\end{array}$ & $\begin{array}{l}\text { Casca } \\
(100)\end{array}$ & $\begin{array}{l}\text { Árvore } \\
(100)\end{array}$ & $\begin{array}{l}\text { Fresca }(50) \\
\text { fresca ou } \\
\text { seca }(50)\end{array}$ & $\begin{array}{l}\text { Maceração } \\
(100)\end{array}$ & $\begin{array}{l}\text { Distúrbios } \\
\text { gastrintestinais (100) }\end{array}$ & $\begin{array}{l}\text { Efeito hipoglicemiante e contra úlcera gástrica } \\
\text { em ratos (NOVELLO et al., 2008) }\end{array}$ \\
\hline $\begin{array}{l}\text { SOLANACEAE } \\
\text { Cestrum nocturnum Duss } \\
\text { (dama da noite) }\end{array}$ & $\begin{array}{c}1 \\
(0,23)\end{array}$ & $\begin{array}{l}\text { Folha e } \\
\text { flor }(100)\end{array}$ & $\begin{array}{c}\text { Árvore } \\
(100)\end{array}$ & Fresca (100) & Infusão (100) & $\begin{array}{c}\text { Distúrbios } \\
\text { cardiovasculares } \\
(100)\end{array}$ & NC \\
\hline $\begin{array}{l}\text { SOLANACEAE } \\
\text { Nicotiana tabacum L. } \\
\text { (fumo) }\end{array}$ & $\begin{array}{c}1 \\
(0,23)\end{array}$ & $\begin{array}{l}\text { Folha } \\
(100)\end{array}$ & $\begin{array}{l}\text { Herbácea } \\
\text { (100) }\end{array}$ & Fresca (100) & $\begin{array}{l}\text { Maceração } \\
(100)\end{array}$ & $\begin{array}{l}\text { Cicatrizante }(100) \text {, } \\
\text { cólica em bebês }(100)\end{array}$ & Atividade anti-helmíntica (IQBAL et al., 2006) \\
\hline $\begin{array}{l}\text { SOLANACEAE } \\
\text { Solanaceae sp1 } \\
\text { (quina) }\end{array}$ & $\begin{array}{c}1 \\
(0,23)\end{array}$ & $\begin{array}{c}\text { Folha e } \\
\text { casca } \\
(100)\end{array}$ & $\begin{array}{l}\text { Arbusto } \\
(100)\end{array}$ & Fresca (100) & Infusão (100) & $\begin{array}{c}\text { Distúrbios } \\
\text { gastrintestinais }(100), \\
\text { refrescante }(100)\end{array}$ & NC \\
\hline $\begin{array}{l}\text { SOLANACEAE } \\
\text { Solanum tuberosum L. } \\
\text { (batata) }\end{array}$ & $\begin{array}{c}1 \\
(0,23)\end{array}$ & $\begin{array}{l}\text { Tubérculo } \\
\text { (100) }\end{array}$ & $\begin{array}{l}\text { Herbácea } \\
\qquad(100)\end{array}$ & Fresca (100) & In natura $(100)$ & $\begin{array}{c}\text { Distúrbios } \\
\text { gastrintestinais }(100), \\
\text { queimaduras }(100)\end{array}$ & NC \\
\hline $\begin{array}{l}\text { VERBENACEAE } \\
\text { Aloysia lycioides Cham. } \\
\text { (cidró) }\end{array}$ & $\begin{array}{c}3 \\
(0,70)\end{array}$ & $\begin{array}{c}\text { Folha } \\
(66,67), \\
\text { folha e } \\
\text { caule } \\
(33,33)\end{array}$ & $\begin{array}{l}\text { Árvore } \\
(66,67), \\
\text { arbusto } \\
(33,33)\end{array}$ & $\begin{array}{c}\text { Fresca } \\
(66,67) \\
\text { fresca ou } \\
\text { seca }(33,33)\end{array}$ & Infusão (100) & $\begin{array}{l}\text { Distúrbios } \\
\text { gastrintestinais (100) }\end{array}$ & $\begin{array}{l}\text { Propriedades aromáticas e possível atividade } \\
\text { antimicrobiana (SANTOS et al., 2013) }\end{array}$ \\
\hline $\begin{array}{l}\text { VERBENACEAE } \\
\text { Lantana camara L. } \\
\text { (quebranteira amarela) }\end{array}$ & $\begin{array}{c}1 \\
(0,23)\end{array}$ & $\begin{array}{c}\text { Folha e } \\
\text { semente } \\
(100)\end{array}$ & $\begin{array}{c}\text { Árvore } \\
(100)\end{array}$ & Fresca (100) & Infusão (100) & Quebranto (100) & $\begin{array}{l}\text { Tônico e febrífugo (MENTZ; SCHENKEL, 1989); } \\
\text { atividade antibacteriana (BOSCOLO; VALLE, } \\
\text { 2008; SOUSA et al., 2011), anti-inflamatória, } \\
\text { analgésica, antipirética e antitumoral } \\
\text { (BOSCOLO; VALLE, 2008) }\end{array}$ \\
\hline $\begin{array}{l}\text { VERBENACEAE } \\
\text { Lantana montevidensis } \\
\text { (Spreng.) Briq. } \\
\text { (quebranteira roxa) }\end{array}$ & $\begin{array}{c}1 \\
(0,23)\end{array}$ & $\begin{array}{l}\text { Parte } \\
\text { aérea } \\
(100)\end{array}$ & $\begin{array}{c}\text { Árvore } \\
(100)\end{array}$ & Fresca (100) & Infusão (100) & Quebranto (100) & Atividade antibacteriana (SOUSA et al., 2011) \\
\hline $\begin{array}{l}\text { VERBENACEAE } \\
\text { Stachytarpheta cayennensis } \\
\text { (Rich.) Vahl } \\
\text { (gervão) }\end{array}$ & $\begin{array}{c}2 \\
(0,47)\end{array}$ & $\begin{array}{l}\text { Parte } \\
\text { aérea } \\
(100)\end{array}$ & $\begin{array}{l}\text { Herbácea } \\
\qquad(100)\end{array}$ & Fresca (100) & $\begin{array}{l}\text { Infusão (50), } \\
\text { decocção (50) }\end{array}$ & $\begin{array}{c}\text { Cicatrizante }(50), \\
\text { antidiabético }(50), \\
\text { doenças respiratórias } \\
\text { (50), antitussígeno (50), } \\
\text { lesão bucal }(50)\end{array}$ & $\begin{array}{l}\text { Hipocolesterolêmico, hipoglicemiante } \\
\text { (BORCARD et al., 2015); estimula as funções } \\
\text { gastrintestinais, útil nas dispepsias, nas } \\
\text { afecções crônicas do fígado (hepatite) e } \\
\text { vermífuga (GRANDI, 2014); propriedades anti- } \\
\text { inflamatórias (SCHAPOVAL et al., 1998) }\end{array}$ \\
\hline $\begin{array}{l}\text { VIOLACEAE } \\
\text { Viola odorata L. } \\
\text { (violeta) }\end{array}$ & $\begin{array}{c}2 \\
(0,47)\end{array}$ & $\begin{array}{l}\text { Parte } \\
\text { aérea } \\
(100)\end{array}$ & $\begin{array}{l}\text { Herbácea } \\
\qquad(100)\end{array}$ & Fresca $(100)$ & $\begin{array}{l}\text { Infusão (50), } \\
\text { decocção (50) }\end{array}$ & $\begin{array}{l}\text { Antitussígeno (100), } \\
\text { anti-helmíntico (50), } \\
\text { doenças respiratórias } \\
\text { (50), garganta (50) }\end{array}$ & $\begin{array}{l}\text { Antibacteriano contra cepas patogênicas do } \\
\text { trato respiratório, asma, bronquite, doença } \\
\text { pulmonar obstrutiva crônica, antipirético, } \\
\text { antitussígeno para crianças com asma (LOPES } \\
\text { et al., 2016) }\end{array}$ \\
\hline $\begin{array}{l}\text { VITACEAE } \\
\text { Cissus verticillata (L.) } \\
\text { Nicolson \& C.E. Jarvis } \\
\text { (insulina) }\end{array}$ & $\begin{array}{c}2 \\
(0,47)\end{array}$ & $\begin{array}{l}\text { Folha } \\
(100)\end{array}$ & $\begin{array}{l}\text { Liana } \\
(100)\end{array}$ & Fresca $(100)$ & $\begin{array}{l}\text { Decocção (50), } \\
\text { maceração (50) }\end{array}$ & $\begin{array}{l}\text { Antidiabético (100), } \\
\text { anti-hipertensivo (50) }\end{array}$ & $\begin{array}{l}\text { Potencial antifúngico, cicatrizante e promissora } \\
\text { quanto à futura utilização de seu extrato no } \\
\text { tratamento da glicemia e triglicerídeos. A fração } \\
\text { acetato de etila do extrato hidroalcoólico } \\
\text { apresentou atividade antioxidante. Segundo a } \\
\text { autora, futuros estudos para avaliar esta } \\
\text { atividade antioxidante podem levar a } \\
\text { identificação de novos compostos antioxidantes } \\
\text { que poderão ser utilizados na terapêutica de } \\
\text { doenças como Diabetes Mellitus e hipertensão } \\
\text { arterial (BRAGA, 2008) }\end{array}$ \\
\hline
\end{tabular}




\begin{tabular}{|c|c|c|c|c|c|c|c|}
\hline $\begin{array}{l}\text { ZINGIBERACEAE } \\
\text { Curcuma longa L. } \\
\text { (açafrão) }\end{array}$ & $\begin{array}{c}3 \\
(0,70)\end{array}$ & $\begin{array}{c}\text { Raiz } \\
(66,67), \\
\text { folha } \\
(33,33)\end{array}$ & $\begin{array}{l}\text { Herbácea } \\
\text { (100) }\end{array}$ & $\begin{array}{c}\text { Fresca } \\
(66,67), \text { seca } \\
(33,33)\end{array}$ & $\begin{array}{l}\text { Maceração } \\
\text { (100) }\end{array}$ & $\begin{array}{c}\text { Antidiabético }(66,67) \text {, } \\
\text { depurativo }(33,33), \\
\text { distúrbios } \\
\text { cardiovasculares } \\
(33,33), \\
\text { hipocolesterolemiante } \\
(33,33) \text {, câncer }(33,33)\end{array}$ & $\begin{array}{l}\text { Antidispéptico e anti-inflamatório. A tintura } \\
\text { possui indicações colerética, colagoga, } \\
\text { hipoglicemiante, antiespasmódica, anti- } \\
\text { flatulenta e anti-inflamatória (BRASIL, 2011); } \\
\text { suas atividades biológicas são atribuídas } \\
\text { principalmente aos curcuminoides contidos na } \\
\text { curcuma. A curcumina apresenta atividade } \\
\text { antioxidante, anti-inflamatória, tendo sido } \\
\text { proposta no tratamento de doenças } \\
\text { degenerativas de caráter inflamatório e } \\
\text { oxidante, p.ex. doenças cardiovasculares, } \\
\text { diabetes tipo 2, artrose e artrite, e seus efeitos } \\
\text { quimiopreventivos para o câncer foram } \\
\text { relatados em vários estudos (WILLIAMSON et } \\
\text { al., 2012); anti-inflamatório inibidor da síntese de } \\
\text { prostaglandinas, inibe o crescimento de } \\
\text { Helicobacter pilorie aumenta a barreira mucosa } \\
\text { (MICHILES; BOTSARIS, 2005), desacelera o } \\
\text { processo de osteoartrite, redução de inflamação } \\
\text { hepática, antibacteriana, contra dispepsia e } \\
\text { colite ulcerativa, gastroprotetora, doenças } \\
\text { digestivas funcionais e orgânicas (LOPES et al., } \\
\text { 2016) }\end{array}$ \\
\hline $\begin{array}{l}\text { ZINGIBERACEAE } \\
\text { Zingiber officinale Roscoe } \\
\text { (gengibre) }\end{array}$ & $\begin{array}{c}14 \\
(3,29)\end{array}$ & Raiz (100) & $\begin{array}{l}\text { Herbácea } \\
\text { (100) }\end{array}$ & $\begin{array}{c}\text { Fresca } \\
(85,71), \\
\text { fresca ou } \\
\text { seca }(14,29)\end{array}$ & $\begin{array}{c}\text { Decocção } \\
(57,14), \text { infusão } \\
(21,43), \\
\text { maceração } \\
(14,29), \text { in } \\
\text { natura }(7,14)\end{array}$ & $\begin{array}{c}\text { Garganta }(50), \text { doenças } \\
\text { respiratórias }(28,57), \\
\text { antitussígeno }(21,43) \text {, } \\
\text { emagrecedor }(21,43) \text {, } \\
\text { distúrbios } \\
\text { gastrintestinais }(14,29) \text {, } \\
\text { enxaqueca }(14,29), \\
\text { analgésico }(7,14), \\
\text { reumatismo }(7,14), \\
\text { anti-hipertensivo } \\
(7,14), \text { desintoxicante } \\
(7,14)\end{array}$ & $\begin{array}{l}\text { Antiemético, antidispéptico, expectorante e nos } \\
\text { casos de cinetose (BRASIL, 2011; BRASIL, } \\
\text { 2016); propriedades carminativa, antiemética, } \\
\text { anti-inflamatória, antiespasmódica e } \\
\text { antiplaquetária (WILLIAMSON et al., 2012); } \\
\text { hepatoprotetor, hipolipidêmico, desordens } \\
\text { gastrintestinais, sedativo, antiemético, reduz a } \\
\text { secreção de muco (LOPES et al., 2016) }\end{array}$ \\
\hline $\begin{array}{l}\text { Não identificada } \\
\text { (breu) }\end{array}$ & $\begin{array}{c}1 \\
(0,23)\end{array}$ & $\begin{array}{l}\text { Resina } \\
(100)\end{array}$ & $\begin{array}{l}\text { Árvore } \\
(100)\end{array}$ & Seca (100) & Pomada (100) & Cicatrizante (100) & - \\
\hline $\begin{array}{l}\text { Não identificada } \\
\text { (figatil) }\end{array}$ & $\begin{array}{c}1 \\
(0,23)\end{array}$ & $\begin{array}{l}\text { Folha } \\
(100)\end{array}$ & $\begin{array}{c}\text { Herbácea } \\
(100)\end{array}$ & Fresca (100) & Infusão (100) & $\begin{array}{c}\text { Distúrbios } \\
\text { gastrintestinais }(100)\end{array}$ & - \\
\hline $\begin{array}{l}\text { Não identificada } \\
\text { (quininha) }\end{array}$ & $\begin{array}{c}1 \\
(0,23)\end{array}$ & $\begin{array}{l}\text { Parte } \\
\text { aérea } \\
(100)\end{array}$ & $\begin{array}{l}\text { Herbácea } \\
\text { (100) }\end{array}$ & Fresca $(100)$ & Infusão (100) & $\begin{array}{l}\text { Cicatrizante }(100) \text {, } \\
\text { lesão bucal }(100)\end{array}$ & - \\
\hline
\end{tabular}

*Espécies ordenadas alfabeticamente por família botânica, sendo nํit. (\%) = número de citações (porcentagem do total de citações, $n=426) ; \% n^{\circ}$ cit. = porcentagem do número de citações; $N C$ = nada consta nas fontes consultadas; propriedade terapêutica em negrito = não referenciada nas fontes consultadas. Nomes científicos conforme Missouri Botanical Garden (2016).

\section{DISCUSSÃO}

O uso de plantas medicinais com finalidade terapêutica é relativamente bem disseminado entre os habitantes da área de abrangência da USF Itambezinho, assim como evidenciado em outras comunidades rurais (JACOBY et al., 2002; NEGRELLE; FORNAZZARI, 2007). De forma similar a outras localidades rurais já avaliadas (JACOBY et al., 2002; NEGRELLE; FORNAZZARI, 2007), o uso estava atrelado a mulheres, com idade média de 41 anos \pm 21 e baixa renda.

No estudo de Pereira et al. (2005), verificou-se que a maior parte dos entrevistados 
possuía renda familiar em média, igual a 1 salário mínimo, e com relação à ocupação, os aposentados (43\%) constituíram o maior número de indivíduos participantes da pesquisa. Löbler et al. (2014), em seu estudo, constataram que a maioria dos entrevistados possuía como escolaridade predominante o $1^{\circ}$ grau incompleto, assim como no presente estudo, e $67 \%$ pertenciam ao sexo feminino.

No estudo de Barros et al. (2007), 92\% dos participantes de pesquisa afirmaram que o conhecimento relacionado ao uso de plantas medicinais foi advindo de tradição familiar, valor próximo ao encontrado no presente estudo $(89,44 \%)$. Esta transferência de conhecimento etnobotânico é caracterizada como "transgeracional", onde a passagem de conhecimento é transmitida de forma oral, a partir de contato intenso entre gerações, principalmente em grupo doméstico e de parentesco. Este tipo de transmissão depende diretamente da integridade familiar e da ausência de pressões migratórias que podem levar os jovens para fora da comunidade, sendo que nesta eventualidade, o conhecimento é perdido com o falecimento dos indivíduos mais velhos (NEGRELLE; FORNAZZARI, 2007).

Barros et al. (2007), em seu estudo, também identificaram que a maioria dos entrevistados faziam uso do material fresco em suas preparações. No estudo de Löbler et al. (2014), a maioria dos entrevistados declararam utilizar a folha, também verificado no estudo de Pereira et al. (2005), e a forma de preparo predominante foi a infusão, assim como no presente estudo, mas em um percentual um pouco maior (71\%); já o modo decocção ou fervura aproximou-se bastante do presente estudo, com 27,6\% das citações. Quanto ao hábito, predominaram espécies herbáceas $(58,3 \%)$ no estudo de Löbler et al. (2014), corroborando com o presente estudo, que obteve um percentual um pouco maior $(65,96 \%)$.

Do total de espécies identificadas (120), foram encontradas indicações na literatura científica de 103 espécies (85,83\%). Destaca-se ainda a importância dos riscos associados, visto que 58,33\% das espécies possuem algum tipo de risco, contraindicação e/ou toxicidade detectada na literatura.

Considerando o conhecimento popular acerca da finalidade de uso das plantas medicinais citadas, observou-se que em 73,33\% das plantas identificadas, pelo menos uma indicação informada pelos populares corrobora com o reportado na literatura científica.

Entretanto, foram verificadas algumas divergências. De acordo com Colussi et al. (2011), a espécie Melissa officinalis L. possui ação antifúngica e antibacteriana, não reportado pelos entrevistados. Segundo Lahlou et al. (2007), a espécie Tanacetum vulgare L. possui forte ação diurética, que também não foi citada pelos participantes do presente 
estudo, bem como a espécie Rosmarinus officinalis L. que possui atividade antimicrobiana contra bactérias Gram-positivas e Gram-negativas (ARRUDA, 2002), não referenciada para esta finalidade. Em estudo, Lessa et al. (2008) constataram efeito anti-hipertensivo da espécie Echinodorus grandiflorus L. em ratos espontaneamente hipertensos.

A não consonância das indicações de uso citadas em relação à literatura consultada pode servir de referencial para estudos adicionais no sentido de ampliar as possibilidades de uso das espécies, bem como comprovar a ineficácia ou impropriedade da citada utilização (NEGRELLE; FORNAZZARI, 2007).

\section{CONCLUSÃO}

\section{REFERÊNCIAS}

ABAD, M.J.; BERMEJO, P. Baccharis (Compositae): a review update. Arkivoc 2007, 7: 76-96.

ADEYEMI, O.O.; OKPO, S.O.; OGUNTI, O.O. Analgesic and anti-inflammatory effects of the aqueous extract of leaves of Persea americana Mill Lauraceae. Fitoterapia, 73 (2002) 375-380.

AFOLAYAN, A.J.; ABOYADE, O.M.; ADEDAPO, A.A.; SOFIDIYA, M.O. Anti-inflammatory and analgesic activity of the methanol extract of Malva parviflora Linn (Malvaceae) in rats. African Journal of Biotechnology, 9(8): 1225-1229, 22 February, 2010.

AHMAD, F.; KHAN, R.A.; RASHEED, S. Study of analgesic and anti-inflammatory activity from plant extracts of Lactuca scariola and Artemisia absinthium. Journal of Islamic Academy of Sciences 5:2, 111-114, 1992.

ALI, N.M.; YEAP, S.K.; HO, W.Y.; BEH, B.K.; TAN, S.W.; TAN, S.G. The Promising Future of Chia, Salvia hispanica L. Journal of Biomedicine and Biotechnology, v. 2012, 9 p., 2012.

ALMEIDA, K.C.; BARBOSA, T.R.; SILVA, R.N.R.; JACQUES, D.S.; FREIRE, R.B. Efeito citotóxico do infuso aquoso de Psidium guajava L. (Myrtaceae). Rev. Bras. Farm., 87(2): 60-62, 2006. 
ALMEIDA, C.; BARBIERI, R.L.; RIBEIRO, M.V.; LOPES, C.V.; HECK, R.M. Espinheirasanta (Maytenus ilicifolia Mart. ex Reiss.): saber de erveiros e feirantes em Pelotas (RS). Rev. Bras. PI. Med., Campinas, v.17, n.4, supl. I, p.722-729, 2015.

ALVES, P.M.; PEREIRA, J.V.; HIGINO, J.S.; PEREIRA, M.S.V.; QUEIROZ, L.M.G. Atividade antimicrobiana e antiaderente in vitro do extrato de Rosmarinus officinalis Linn. (alecrim) sobre microrganismos cariogênicos. Arquivos em Odontologia, v.44, n.2, abr./jun. 2008.

ALVES, P.M.; QUEIROZ, L.M.G.; PEREIRA, J.V.; PEREIRA, M.S.V. Atividade antimicrobiana, antiaderente e antifúngica in vitro de plantas medicinais brasileiras sobre microrganismos do biofilme dental e cepas do gênero Candida. Revista da Sociedade Brasileira de Medicina Tropical, 42(2):222-224, mar-abr, 2009.

AMIN, B. F.; OLIVA, M. P. Estudio comparativo entre terapia con Melissa officinalis vs. tratamiento convencional com aciclovir tópico al $5 \%$ para lesiones herpéticas tipo 1. Int. J. Odontostomat., 8(3):323-328, 2014.

AMORIM, J.A. Fitoterapia popular e saúde da comunidade: diagnóstico para proposta de integração nos serviços de saúde em Campina Grande, PB, Brasil. Tese. Bauru, São Paulo: Universidade de São Paulo. 1999. 170p.

ANDRADE, J.T.; DA COSTA, L.F.A. Medicina Complementar no SUS: práticas integrativas sob a luz da Antropologia médica. Saúde Soc. São Paulo, v.19, n.3, p.497-508, 2010.

ARCANJO, D.D.R.; SENA, I.V.O.; ALBUQUERQUE, A.C.M.; NETO, B.M.; SANTANA, L.C.L.R.; SILVA, N.C.B.; MOITA, M.M.; MEDEIROS, M.G.F.; SOARES, M.J.S.; ANDRADE, N.C.; CITÓ, A.M.G.L. Phytochemical screening and evaluation of cytotoxic, antimicrobial and cardiovascular effects of Gomphrena globosa L. (Amaranthaceae). J. Med. Plant. Res., v.5(10), pp.2006-2010, may. 2011.

ARIAS, B.A.; RAMÓN-LACA, L. Pharmacological properties of citrus and their ancient and medieval uses in the Mediterranean region. Journal of Ethnopharmacology 97 (2005) 8995. 
ARRUDA, T.A. Estudo etnofarmacobotânico e atividade antimicrobiana de plantas medicinais. Dissertação. Campina Grande, Paraíba: Universidade Estadual da Paraíba. 2002. 94p.

ASSIS, C. Plantas medicinais na odontologia. Rev. bras. odontol.., Rio de Janeiro, v.66, n.1, p.72-75, jan./jun. 2009.

AURICCHIO, M.T.; BUGNO, A.; BARROS, S.B.M.; BACCHI, E.M. Atividades Antimicrobiana e Antioxidante e Toxicidade de Eugenia uniflora. Lat. Am. J. Pharm. 26 (1): 76-81, 2007.

BADKE, M.R.; BUDÓ, M.L.D.; SILVA, F.M.; RESSEL, L.B. Plantas medicinais: o saber sustentado na prática do cotidiano popular. Esc Anna Nery (impr.) 2011, jan./mar., 15 (1):132-139.

BALEN, E. Atividade analgésica do extrato de Schinus terebinthifolius e de derivados 1,2,3,4,6-Pentagaloil-O-B-Glucopiranosideo e Robustaflavona em modelos experimentais de nocicepção em roedores. Dissertação (Mestrado em Ciências da Saúde). Universidade Federal da Grande Dourados. Dourados, MS: UFGD, 2015. 52f.

BARROS, F.M.C; PEREIRA, K.N.;ZANETTI, G.D.; HEINZMANN, B.M. Plantas de Uso Medicinal no Município de São Luiz Gonzaga, RS, Brasil. Lat. Am. J. Pharm. 26 (5): 652-62, 2007.

BERNAERT, N.; PAEPE, D.; BOUTEN, C.; CLERCQ, H.; STEWART, D.; BOCKSTAELE, E.V.; LOOSE, M.; DROOGENBROECK, B.V. Antioxidant capacity, total phenolic and ascorbate content as a function of the genetic diversity of leek (Allium ampeloprasum var. porrum). Food Chemistry 134 (2012) 669-677.

BHASIN, M. Ocimum- Taxonomy, medicinal potentialities and economic value of essential oil. Journal of Biosphere, 1: 48-50, 2012.

BONELLA, A.F.; NATALLI, V.D.; CAMIZÃO, L.M.; VIEIRA, F.A.; BELINELO, V.J. Estudo fitoquímico e atividade antibacteriana de extratos de folhas de Acanthospermum australe (Loerfl.) Kuntze. Enciclopédia Biosfera, Centro Científico Conhecer, Goiânia, v.7, n.13, 2011. 
BONI, A.P.; ZENI, A.L.B.; ALBUQUERQUE, C.A.C. Efeito do extrato hidroalcoólico de Tabernaemontana catharinensis em camundongos inoculados experimentalmente com veneno botrópico. Rev. Bras. Farm. 92(3): 176-185, 2011.

BORCARD, G.G.; CONDE, B.E.; ALVES, M.J.M.; CHEDIER, L.M.; PIMENTA, D.S. Estudo etnofarmacológico em entorno de floresta urbana como subsídio para a implantação da Fitoterapia no Sistema Único de Saúde. Rev. Bras. PI. Med., Campinas, v.17, n.4, supl. II, p.928-936, 2015.

BOSCOLO, O.H.; VALLE, L.S. Plantas de uso medicinal em Quissamã, Rio de Janeiro, Brasil. IHERINGIA, Sér. Bot., Porto Alegre, v.63, n.2, p.263-277, jul./dez. 2008.

BOZORGI, M.; AMIN, G.; SHEKARCHI, M.; RAHIMI, R. Traditional medical uses of Drimia species in terms of phytochemistry, pharmacology and toxicology. J Tradit Chin Med 2017 February 15; 37(1): 124-139.

BRAGA, T.V. Avaliação da atividade farmacológica de Cissus verticillata Nicolson \& C. E. Jarvis subsp verticillata como antioxidante, antifúngico, hipoglicemiante e cicatrizante. Dissertação (Mestrado). Universidade Federal de Ouro Preto. Escola de Farmácia. Programa de Pós-graduação em Ciências Farmacêuticas. Ouro Preto, MG, 2008.

BRASIL. Ministério da Saúde. Secretaria de Ciência, Tecnologia e Insumos Estratégicos. Departamento de Assistência Farmacêutica. Política nacional de plantas medicinais e fitoterápicos. Brasília: Ministério da Saúde, 2006a. 60 p. - (Série B. Textos Básicos de Saúde).

BRASIL. Ministério da Saúde. Gabinete do Ministro. Portaria oํ 971, de 3 maio de 2006. Aprova a Política Nacional de Práticas Integrativas e Complementares (PNPIC) no Sistema Único de Saúde. Diário Oficial da União, Brasília, DF, n. 84, p.20-25, 4 mai. 2006b. Seção 1. Disponível em: <http://bvsms.saude.gov.br/bvs/saudelegis/gm/2006/prt0971_03_05_ 2006.html>. Acesso em: 16 out. 2016.

BRASIL. Poder Executivo. Decreto № 5.813, de 22 de junho de 2006. Aprova a Política Nacional de Plantas Medicinais e Fitoterápicos e dá outras providências. Diário Oficial da 
União, Brasília, DF, n. 119, p.2-4, 23 jun. 2006c. Seção 1. Disponível em: $<$ http://pesquisa.in.gov.br/imprensa/jsp/visualiza/index.jsp?jornal=1\&pagina=2\&data=23/06 /2006>. Acesso em: 16 out. 2016.

BRASIL. Agência Nacional de Vigilância Sanitária. Formulário de Fitoterápicos da Farmacopeia Brasileira. Brasília: Anvisa, 2011. 126p.

BRASIL. Ministério da Saúde. Secretaria de Atenção à Saúde. Departamento de Atenção Básica. Práticas integrativas e complementares: plantas medicinais e fitoterapia na Atenção Básica. Brasília: Ministério da Saúde, 2012; 156 p. il. - (Série A. Normas e Manuais Técnicos) (Cadernos de Atenção Básica; n. 31).

BRASIL. Ministério da Saúde. Secretaria de Atenção à Saúde. Departamento de Atenção Básica. Política Nacional de Práticas Integrativas e Complementares no SUS: atitude de ampliação de acesso. 2. ed. Brasília: Ministério da Saúde, 2015; 96 p. il.

BRASIL. Agência Nacional de Vigilância Sanitária. Memento Fitoterápico da Farmacopeia Brasileira. 1. ed. Brasília: Anvisa, 2016. 115p.

BUFFON, M.C.M.; LIMA, M.L.C.; GALARDA, I.; COGO, L. Avaliação da eficácia dos extratos de Malva sylvestris, Calêndula officinalis, Plantago major e Curcuma zedoarea no controle do crescimento das bactérias da placa dentária. Estudo “in vitro". Revista Visão Acadêmica, Curitiba, v. 2, n. 1, p. 31-38, jan./jun. 2001.

CAETANO, N.N.; FONTE, J.R.; BORSATO, A.V. Sistemas de produção de plantas medicinais na região metropolitana de Curitiba. Rev. Bras. Farmacogn., v.13, supl., p.74-77, 2003.

CAMPELO, C.R. Contribuição ao estudo das plantas medicinais no Estado de Alagoas V. Supl. Acta Amazonica, 18(1-2): 305-312, 1988.

CANDAN, F.; UNLU, M.; TEPE, B.; DAFERERA, D.; POLISSIOU, M.; SÖKMEN, A.; AKPULAT, H.A. Antioxidant and antimicrobial activity of the essential oil and methanol extracts of Achillea millefolium subsp. millefolium Afan. (Asteraceae). J Ethnopharmacol. 2003 Aug; 87(2-3):215-20. 
CARDOSO, C.M.Z.; SILVA, C.P.; YAMAGAMI, K.; LOPES, R.P.; SANTOS, F.; BONASSI, I.; JESUÍNO, I.; GERES, F.; MARTORIE JR., T.; GRAÇA, M.; KANEKO, B.; PAVANI, E.; INOWE, C. Elaboração de uma Cartilha Direcionada aos Profissionais da Área da Saúde, Contendo Informações sobre Interações Medicamentosas envolvendo Fitoterápicos e Alopáticos. Revista Fitos, v.4, n.1, mar. 2009.

CARVALHO, A.F.; SILVA, D.M.; SILVA, T.R.C.; SCARCELLI, E.; MANHANI, M.R. Avaliação da atividade antibacteriana de extratos etanólico e de ciclohexano a partir das flores de camomila (Matricaria chamomilla L.). Rev. Bras. PI. Med., Campinas, v.16, n.3, p.521-526, 2014.

CAVALCANTE, A.L.F.A. Plantas medicinais e saúde bucal: estudo etnobotânico, atividade antimicrobiana e potencial para interação medicamentosa. Dissertação (Mestrado). Universidade Federal da Paraíba. Programa de Pós-graduação em Odontologia. João Pessoa, PB, 2010. $206 \mathrm{f}$.

CHAGAS, J.H.; PINTO, J.E.B.P.; BERTOLUCCI, S.K.V.; SANTOS, F.M. Produção de biomassa e teor de óleo essencial em função da idade e época de colheita em plantas de hortelã-japonesa. Acta Scientiarum. Agronomy, Maringá, v. 33, n. 2, p. 327-334, 2011.

CHAGAS, J.H.; PINTO, J.E.B.P.; BERTOLUCCI, S.K.V.; COSTA, A.G.; JESUS, H.C.R.; ALVES, P.B. Produção, teor e composição química do óleo essencial de hortelã-japonesa cultivada sob malhas fotoconversoras. Hortic. bras., v. 31, n. 2, abr.jjun. 2013.

COLUSSI, T.C.; DALMOLIN, L.F.; PACHTMANN, M.; FREITAS, G.B.L. Melissa officinalis L.: características gerais e biossíntese dos principais metabólitos secundários. Revista de Biologia e Farmácia, v.5, n.2, 2011.

CORRÊA, C.F.; BIASI, L.A. Área foliar e tipo de substrato na propagação por estaquia de cipó-mil-homens (Aristolochia triangularis Cham. et Schl.). R. bras. Agrociência, v.9, n.3, p. 233-235, jul-set, 2003.

COSMO, S.A.; MAYER, B.; FREITAS, C.S.; BAGGIO, C.H.; MARQUES, M.C.A. Gastroprotective effect of hydroalcoholic extract from barks of Persea major Kopp (Lauraceae) in rats. Rev. Bras. Farmacogn. 17(4): 533-537, out./dez. 2007. 
COSTA, V.P.; MAYWORM, M.A.S. Plantas medicinais utilizadas pela comunidade do bairro dos Tenentes - município de Extrema, MG, Brasil. Rev. Bras. PI. Med., Botucatu, v.13, n.3, p.282-292, 2011.

CRESTANI, S.; RATTMANN; Y.D.; CIPRIANI, T.R.; SOUZA, L.M.; IACOMINI, M.; KASSUYA, C.A.; MARQUES, M.C.; SILVA-SANTOS, J.E. A potent and nitric oxide dependent hypotensive effect induced in rats by semi-purified fractions from Maytenus ilicifolia. Vascul Pharmacol. 2009 Jul;51(1):57-63.

CRUCES, I.L.; PATELLI, T.H.C.; TASHIMA, C.M.; MELLO-PEIXOTO, E.C.T. Plantas medicinais no controle de urolitíase. Rev. Bras. PI. Med., Campinas, v.15, n.4, supl.I, p.780788, 2013.

CRUZ, V.B.; TRESVENZOL, L.M.F.; FERREIRA, H.D.; PAULA, J.R.; PAULINO, N.P. Leonotis nepetifolia (L.) R. Br. (cordão-de-frade): biologia e uso tradicional. Rev. Pesq. Inov. Farm. 3(1), 2011, 15-28.

DELAPORTE, R.H.; GUZEN, K.P.; TAKEMURA, O.S.; MELLO, J.C.P. Estudo mineral das espécies vegetais Alternanthera brasiliana (L.) Kuntze e Bouchea fluminensis (Vell) Mold. Rev. Bras. Farmacogn. 15(2): abr/jun. 2005.

DORNAS, W.C.; OLIVEIRA, T.T.; DORES, R.G.R.; FABRES, M.H.A.; NAGEM, T.J. Efeitos antidiabéticos de plantas medicinais. Rev. Bras. Farmacogn. 19(2A): abr./jun. 2009.

FANTE, C.A.; DIETERISH, S.; RODRIGUEZ, R. Betametasona e extrato aquoso de Arctium lappa no tratamento da angiostrongilíase. Revista da Sociedade Brasileira de Medicina Tropical. 41(6):654-657, nov-dez, 2008.

FAYED, S.A. Antioxidant and Anticancer Activities of Citrus reticulate (Petitgrain Mandarin) and Pelargonium graveolens (Geranium) Essential Oils. Res. J. Agric. \& Biol. Sci., 5(5): 740-747, 2009.

FIDALGO, O.; BONONI, V.L.R. Técnica de coleta, preservação e herborização de material botânico. (Série Documentos) São Paulo. 62p. 1989. 
FOGANHOLI, A.P.A.M.; DANIEL, J.F.S.; SANTIAGO, D.C.; ORIVES, J.R.; PEREIRA, J.P.; FARIA, T.J. Chemical composition and antifungal activity of pennyroyal essential oil in different stages of development. Semina: Ciências Agrárias, Londrina, v. 36, n. 5, p. 30913100, set./out. 2015.

FRANCISCO, K.M.S. Fitoterapia: Uma opção para o tratamento odontológico. Saúde Revista, 2010; 4(1):18-24.

GAZIM, Z.C.; AMORIM, A.C.L.; HOVELL, A.M.C.; REZENDE, C.M.; NASCIMENTO, I.A.; FERREIRA, G.A.; CORTEZ, D.A.G. Seasonal Variation, Chemical Composition, and Analgesic and Antimicrobial Activities of the Essential Oil from Leaves of Tetradenia riparia (Hochst.) Codd in Southern Brazil. Molecules. 2010, 15(8), 5509-5524.

GHANNADI, A.; BAGHERINEJAD, M.R.; ABEDI, D.; JALALI, M.; ABSALAN, B.; SADEGHI, N. Antibacterial activity and composition of essential oils from Pelargonium graveolens L'Her and Vitex agnus-castus L. Iran. J. Microbiol. 4 (4): 171-176, 2012.

GIL, A.C. Como elaborar projetos de pesquisa. 4. ed. São Paulo: Atlas, 2002.

GONÇALVES, A.L.; ALVES FILHO, A.; MENEZES, H. Estudo comparativo da atividade antimicrobiana de extratos de algumas árvores nativas. Arq. Inst. Biol., São Paulo, v.72, n.3, p.353-358, jul./set., 2005.

GONÇALVES, D.M.; ARAÚJO, J.H.B.; FRANCISCO, M.S.; COELHO, M.A.; FRANCO, J.M. Avaliação da atividade antimicrobiana in vitro do extrato de Tabernaemontana catharinensis A. DC. Rev. Bras. PI. Med., Botucatu, v.13, n.2, p.197-202, 2011.

GONÇALVES, Z.A.; MACEDO, M.; LIMA, E.; ARANHA, A.M.F.; PEREIRA, I.C.L.; LENZA, J.B.; VIEIRA, E.M.M. Alternativas terapêuticas para tratamento de afecções bucais no idoso. Rev Odontol Bras Central. 2014; 23(66).

GRANDI, T.S.M. Tratado das plantas medicinais [recurso eletrônico]: mineiras, nativas e cultivadas. 1. ed. Dados eletrônicos. Belo Horizonte: Adaequatio Estúdio, 2014. 1204 p.: il. color. 
GUERREIRO, K.K.; BOBEK, V.; SANTOS, V.L.P.; FRANCO, C.R.C.; PAULA, J.P.; FARAGO, P.V.; BUDEL, J.M. Análise farmacobotânica de folha e caule de Tanacetum vulgare (L.). Rev. Bras. PI. Med., Campinas, v.18, n.1, p.89-95, 2016.

GUILLÉN, M.E.N.; EMIM, J.A.S.; SOUCCAR, C.; LAPA, A.J. Analgesic and Anti inflammatory Activities of the Aqueous Extract of Plantago major L. International Journal Of Pharmacognosy, v. 35, Iss. 2, 1997.

HAEFFNER, R.; HECK, R.M.; CEOLIN, T.; JARDIM, V.M.R.; BARBIERI, R.L. Plantas medicinais utilizadas para o alívio da dor pelos agricultores ecológicos do Sul do Brasil. Rev. Eletr. Enf. 2012; jul/sep;14(3):596-602.

HASAN, S.M.R.; HOSSAIN, M.M.; AKTER, R.; JAMILA, M.; MAZUMDER, M.E.H.; ALAM, M.A.; FARUQUE, A.; RANA, S.; RAHMAN, S. Analgesic activity of the different fractions of the aerial parts of Commelina benghalensis Linn. International Journal of Pharmacology, v.6, n.1, p.63-67, 2010.

HOLETZ, F.B.; PESSINI, G.L.; SANCHES, N.R.; CORTEZ, D.A.G.; NAKAMURA, C.V.; DIAS FILHO, B.P. Screening of Some Plants Used in the Brazilian Folk Medicine for the Treatment of Infectious Diseases. Mem Inst Oswaldo Cruz, Rio de Janeiro, 97(7): 10271031, October 2002.

HOMAMI, S.S.; JAIMAND, K.; REZAEE, M.B.; AFZALZADEH, R. Comparative studies of different extraction methods of essential oil from Matricaria recutita L. in Iran. J. Chil. Chem. Soc., 61, n.2, 2016.

HSOUNA, A.B.; HAMDI, N. Phytochemical composition and antimicrobial activities of the essential oils and organic extracts from pelargonium graveolens growing in Tunisia. Lipids in Health and Disease 2012, 11:167.

IBGE. Instituto Brasileiro de Geografia e Estatística. Manual técnico da vegetação brasileira. 2. ed. rev. e ampl. Rio de Janeiro, 2012.

INFOPÉDIA. Dicionário infopédia de Termos Médicos [em linha]. Porto: Porto Editora, 
2003-2017. Disponível em: <https://www.infopedia.pt/dicionarios/termos-medicos>. Acesso em: 05 jun. 2017.

IPARDES. Instituto Paranaense de Desenvolvimento Econômico e Social: Caderno Estatístico. Município de Campo Largo. Abril 2016. Disponível em: <http://www.ipardes.gov.br/cadernos/MontaCadPdf1.php?Municipio=83600> Acesso em: 09 out 2016.

IQBAL, Z.; LATEEF, M.; JABBAR, A.; GHAYUR, M.N.; GILANI, A.H. In vitro and In vivo Anthelmintic Activity of Nicotiana tabacum L. Leaves Against Gastrointestinal Nematodes of Sheep. Phytother. Res. 20, 46-48, 2006.

ISLAM, M.A.; AHMED, F.; DAS, A.K.; BACHAR, S.C. Analgesic and anti-inflammatory activity of Leonurus sibiricus. Fitoterapia. 2005 Jun;76(3-4):359-62.

JACOBY, C.; COLTRO, E.M.; SLOMA, D.C.; MÜLLER, J.; DIAS, L.A.; LUFT, M.; BERUSKI, P. Plantas medicinais utilizadas pela comunidade rural de Guamirim, Município de Irati, PR. Revista Ciências Exatas e Naturais, v.4, n.1, jan./jun. 2002.

JOSHI, B.; LEKHAK, S.; SHARMA, A. Antibacterial Property of Different Medicinal Plants: Ocimum sanctum, Cinnamomum zeylanicum, Xanthoxylum armatum and Origanum majorana. Kathmandu University Journal of Science, Engineering and Technology, v.5, n.1, jan. 2009, p.143-150.

KEE, N.L.A.; MNONOPI, N.; DAVIDS, H.; NAUDÉ, R.J.; FROST, C.L. Antithrombotic/anticoagulant and anticancer activities of selected medicinal plants from South Africa. African Journal of Biotechnology, v.7 (3), pp.217-223, 5 February, 2008.

KIM, M.J.; PARK, H.J.; HONG, M.S.; PARK, H.J.; KIM, M.S.; LEEM, K.H.; KIM, J.B.; KIM, Y.J.; KIM, H.K. Citrus Reticulata blanco induces apoptosis in human gastric cancer cells SNU-668. Nutrition and Cancer. 2005; 51(1):78-82.

LACERDA, A.M.; MODOLO, A.K.; MATIAS, R.C.; PISTORI, H.; YANO, M.; ROEL, A.R.; PORTO, K.R.A. Screening de plantas com potencial fitotóxico. Rev. Bras. Farm. 92(4): 352-355, 2011. 
LAHLOU, S., TAHRAOUI, A., ISRAILI, Z., LYOUSSI, B. Diuretic activity of the aqueous extracts of Carum carvi and Tanacetum vulgare in normal rats. J Ethnopharmacol. 2007 Apr;110(3):458-463.

LESSA, M.A.; ARAÚJO, C.V.; KAPLAN, M.A.; PIMENTA, D.; FIGUEIREDO, M.R.; TIBIRIÇÁ, E. Antihypertensive effects of crude extracts from leaves of Echinodorus grandiflorus. Fundam Clin Pharmacol. 2008 Apr; 22(2):161-8.

LÖBLER, L.; SANTOS, D.; RODRIGUES, E.S.; SANTOS, N.R.Z. Levantamento etnobotânico de plantas medicinais no bairro Três de Outubro da cidade de São Gabriel, RS, Brasil. R. Bras. Bioci., Porto Alegre, v. 12, n. 2, p. 81-89, abr./jun. 2014.

LOPES-MARTINS, R.A.; PEGORARO, D.H.; WOISKY, R.; PENNA, S.C.; SERTIÉ, J.A. The anti-inflammatory and analgesic effects of a crude extract of Petiveria alliacea $\mathrm{L}$. (Phytolaccaceae). Phytomedicine. 2002 Apr;9(3):245-8.

LOPES, N.S.; CONDE, B.E.; FONSECA, A.S.; MACEDO, A.L.; CAMPOS, B.C. Medicina complementar e alternativa no contexto da ayurveda e da medicina popular no Brasil. Perspectivas online: biol. \& saúde, Campos dos Goytacazes, 20 (6), 30-44, 2016.

LUIZE, P.S.; TIUMAN, T. S.; MORELLO, L.G.; MAZA, P. K.; UEDA-NAKAMURA, T.; DIAS FILHO, B.P.; CORTEZ, D.A.G.; MELLO, J.C.P.; NAKAMURA, C.V. Effects of medicinal plant extracts on growth of Leishmania (L.) amazonensis and Trypanosoma cruzi. Brazilian Journal of Pharmaceutical Sciences, v.41, n.1, jan./mar., 2005.

LUSA, M.G.; BIASI, L.A. Estaquia de Cuphea calophylla subsp. mesostemon (Koehne) Lourteig (Lythraceae). Rev. Bras. PI. Med., Botucatu, v.13, n.1, p.52-57, 2011.

LUZ, J.M.Q.; SILVA, S.M.; HABBER, L.L.; MARQUEZ, M.O.M. Produção de óleo essencial de Melissa officinalis L. em diferentes épocas, sistemas de cultivo e adubações. Rev. Bras. PI. Med., Campinas, v.16, n.3, p.552-560, 2014.

LUZ, L.E.C.; PALUDO, K.S.; SANTOS, V.L.P.; FRANCO, C.R.C.; KLEIN, T.; SILVA, R.Z.; BELTRAME, F.L.; BUDEL, J.M. Cytotoxicity of latex and pharmacobotanical study of leaves 
and stem of Euphorbia umbellata (Janaúba). Revista Brasileira de Farmacognosia, v. 25, p.344-352, 2015.

MACHADO, G.R.M. Determinação da atividade antifúngica de Acca sellowiana. Dissertação (Mestrado). Universidade Federal do Rio Grande do Sul. Programa de Pósgraduação em Microbiologia Agrícola e do Ambiente. Porto Alegre, RS, 2015. 108 f.

MAHBOUBI, M.; HAGHI, G. Antimicrobial activity and chemical composition of Mentha pulegium L. essencial oil. Journal of Ethnopharmacology, v. 119, n. 2, p. 325-327, 2008.

MALINOWSKI, L.R.L.; ROSA, E.A.R.; PICHETH, C.M.T.F.; CAMPELO, P.M.S. Atividade antimicrobiana dos extratos aquoso e hidroalcoólico de folhas de Artemisia vulgaris. Rev. Bras. Farm., 88(2): 63-66, 2007.

MANSOURABADI, A.H.; SADEGHI, H.M.; RAZAVI, N.; REZVANI, E. Anti-inflammatory and Analgesic Properties of Salvigenin, Salvia officinalis Flavonoid Extracted. Advanced Herbal Medicine, 2015; 1(3): 31-41.

MARQUES, L.C. Phyllanthus niruri (Quebra-Pedra) no Tratamento de Urolitíase: Proposta de Documentação para Registro Simplificado como Fitoterápico. Revista Fitos, v.5, n.3, set. 2010.

MARTINS, M.B.G.; MARTINS, R.G.; CAVALHEIRO, J.A. Histoquímica e atividade antibacteriana de folhas do incenso (Tetradenia riparia). Revista Biociências, UNITAU, v.14, n. 2, 2008.

MARTINS-RAMOS, D.; BORTOLUZZI, R.L.C.; MANTOVANI, A. Plantas medicinais de um remascente de Floresta Ombrófila Mista Altomontana, Urupema, Santa Catarina, Brasil. Rev. Bras. PI. Med., Botucatu, v.12, n.3, p.380-397, 2010.

MELLO, M.; BUDEL, J.M. Equisetum L. (Equisetaceae): uma revisão. Cadernos da Escola de Saúde, Curitiba, v.1, n.9, p.1-15, 2013.

MENTZ, L.A.; SCHENKEL, E.P. Plantas medicinais: a coerência e a confiabilidade das indicações terapêuticas. Caderno de Farmácia, v.5, n.1/2, p.93-119, 1989. 
MICHILES, E.; BOTSARIS, A. S. Medicamentos Sintéticos e Fitoterápicos: Potencialidades de Equivalência. Revista Fitos, v.1, n.1, jun. 2005.

MILANESI, P.M.; BLUME, E.; MUNIZ, M.F.B.; BRAND, S.C.; JUNGES, E.; MANZONI, C.G.; WEBER, M.N.D. Ação fungitóxica de extratos vegetais sobre o crescimento micelial de Colletotrichum gloeosporioides. Revista da FZVA. Uruguaiana, v.16, n.1, p.01-13. 2009.

MIRANDA, J.A.L.; ROCHA, J.A.; ARAÚJO, K.M.; QUELEMES, P.V.; MAYO, S.J., ANDRADE, I.M. Atividade antibacteriana de extratos de folhas de Montrichardia linifera (Arruda) Schott (Araceae). Rev. Bras. PI. Med., Campinas, v.17, n.4, supl. III, p.1142-1149, 2015.

MISSOURI BOTANICAL GARDEN. Tropicos.org. Missouri Botanical Garden. Disponível em: <http://www.tropicos.org>. Acesso em: 02 nov. 2016.

MORAIS, S.M.; DANTAS, J.D.P.; SILVA, A.R.A.; MAGALHÃES, E.F. Plantas medicinais usadas pelos índios Tapebas do Ceará. Revista Brasileira de Farmacognosia. 15(2): 169177, abr./jun. 2005.

MOTA, N.F.O.; PAULA, L.F.; VIANA, P.L. Guia prático de métodos de campo para estudos de flora. Bocaina Biologia da Conservação. $2^{\underline{a}}$ ed. Belo Horizonte, MG, 2014.

NEGRELLE, R.R.B.; FORNAZZARI, K.R.C. Estudo etnobotânico em duas comunidades rurais (Limeira e Ribeirão Grande) de Guaratuba (Paraná, Brasil). Rev. Bras. PI. Med., Botucatu, v.9, n.2, p.36-54, 2007.

NEGRELLE, R.R.B.; TOMAZZONI, M.I.; CECCON, M.F.; VALENTE, T.P. Estudo etnobotânico junto à Unidade Saúde da Família Nossa Senhora dos Navegantes: subsídios para o estabelecimento de programa de fitoterápicos na Rede Básica de Saúde do Município de Cascavel (Paraná). Rev. Bras. PI. Med., Botucatu, v.9, n.3, p.6-22, 2007.

NETO, A.G.; COSTA, J.M.L.C.; BELATI, C.C.; VINHÓLIS, A.H.C.; POSSEBOM, L.S.; SILVA FILHO, A.A.; CUNHA, W.R.; CARVALHO, J.C.T.; BASTOS, J.K.; SILVA, M.L.A. Analgesic and anti-inflammatory activity of a crude root extract of Pfaffia glomerata (Spreng) Pedersen. Journal of Ethnopharmacology 96 (2005) 87-91. 
NITZ, A.C.; ELY, J.B.; D'ACAMPORA, J.; TAMES, D.R.; CORRÊA, B.P. Estudo morfométrico no processo de cicatrização de feridas cutâneas em ratos, usando: Coronopu didymus e Calendula officinali. Arquivos Catarinenses de Medicina, v.35, n.4, 2006.

NOVELLO, C.R.; BAZOTTE, R.B.; BERSANI-AMADO, C.A.; MARQUES, L.C.; CORTEZ, D.A.G. Toxicological and Pharmacological Studies of Picrasma crenata (Vell.) Engler (Simaroubaceae) in Mice and Rats. Lat. Am. J. Pharm. 27 (3): 345-8, 2008.

OKUNADE, A.L. Ageratum conyzoides L.(Asteraceae). Fitoterapia, v.73, n.1, p.1-16, 2002. OLIVEIRA, M.J.R.; SIMÕES, M.J.S.; SASSI, C.R.R. Fitoterapia no Sistema de Saúde Pública (SUS) no Estado de São Paulo, Brasil. Rev. Bras. PI. Med., Botucatu, v.8, n.2, p. 39-41, 2006.

OLIVEIRA, F.Q.; GOBIRA, B.; GUIMARÃES, C. BATISTA, J.; BARRETO, M.; SOUZA M. Espécies vegetais indicadas na odontologia. Revista Brasileira de Farmacognosia. 17(3): 466-476, jul./set. 2007.

OLIVEIRA, L.S.; MUZITANO, M.F.; COUTINHO, M.A.S.; MELO, G.O.; COSTA, S.S. Plantas Medicinais como Recurso Terapêutico em Comunidade do Entorno da Reserva Biológica do Tinguá, RJ, Brasil - Metabólitos Secundários e Aspectos Farmacológicos. Inter Science Place - Revista Científica Internacional, ano 4, n.17, p.54-74, abr./jun. 2011.

OLIVEIRA, A.C.B.; OLIVEIRA, A.P.; GUIMARÃES, A.L.; OLIVEIRA, R.A.; SILVA, F.S.; REIS, S.A.G.B.; RIBEIRO, L.A.A.; ALMEIDA, J.R.G.S. Avaliação toxicológica pré-clínica do chá das folhas de Morus nigra L. (Moraceae). Rev. Bras. PI. Med., Campinas, v.15, n.2, p.244-249, 2013.

PENNAFORT, V.P.S.; FREITAS, C.H.A.; JORGE, M.S.B.; QUEIROZ, M.V.O.; AGUIAR, C.A.A. Práticas integrativas e o empoderamento da enfermagem. Rev. Min. Enferm.; 16(2):289-295, abr./jun., 2012.

PEREIRA, C.O.; LIMA, E.O.; OLIVEIRA, R. A.G.; TOLEDO, M.S.; AZEVEDO, A.K.A.; GUERRA, M.F.; PEREIRA, R.C. Abordagem etnobotânica de plantas medicinais utilizadas em dermatologia na cidade de João Pessoa-Paraíba, Brasil. Rev. Bras. PI. Med., Botucatu, 
v.7, n.3, p.9-17, 2005.

PEREIRA, P.A. Investigação química de Sorocea bonplandii (Baillon) Burger, Lanjouw e Boer (Moraceae). Dissertação (Mestrado). Universidade Federal de Santa Catarina. Centro de Ciências da Saúde. Programa de Pós-Graduação em Farmácia. Florianópolis, SC, 2005.

PEREIRA, C.B.; MARIN, A.; DALMORA, S.L.; NECCHI, R.M.M.; MORESCO, R.N.; MANFRON, M.P. Atividade Anti-inflamatória e Avaliação da Toxicidade do Extrato Hidroetanólico de Morus alba (Moraceae). Rev Ciênc Farm Básica Apl., 2013; 34(1):4346.

PESSINI, G.L.; HOLETZ, F.B.; SANCHES, N.R.; CORTEZ, D.A.G.; DIAS FILHO, B.P.; NAKAMURA, C.V. Avaliação da atividade antibacteriana e antifúngica de extratos de plantas utilizados na medicina popular. Rev. Bras. Farmacogn., v.13, supl., p.21-24, 2003.

POTRICH, F.B.; BAGGIO, C.H.; FREITAS, C.S.; MAYER, B.; SANTOS, A.C.; TWARDOWSCHY, A.; GUEDES, A.; MARQUES, M.C.A. Ação de extratos de plantas medicinais sobre a motilidade do trato gastrointestinal. Rev. Bras. PI. Med., Campinas, v.16, n.3, supl. I, p.750-754, 2014

PRUDENTE, R.C.C.; MOURA, R.B. Evidências científicas para a indicação popular de algumas espécies da família Rutaceae no tratamento de doenças respiratórias na região Sudeste do Brasil. Infarma, v.25, n.1, 2013.

QNAIS, E.Y.; ABU-DIEYEH, M.; ABDULLA, F.A.; ABDALLA, S.S. The antinociceptive and anti-inflammatory effects of Salvia officinalis leaf aqueous and butanol extracts. Pharm Biol. 2010 Oct;48(10):1149-56.

QUEIROZ, J.M.G.; SUZUKI, M.C.M.; MOTTA, A.P.R.; NOGUEIRA, J.M.R.; CARVALHO, E.M. Aspectos populares e científicos do uso de espécies de Eugenia como fitoterápico. Revista Fitos, Rio de Janeiro, v.9(2): 73-159, abr./jun. 2015.

REIS, G.D. Avaliação da atividade biológica do taro [(Colocasia esculenta (L.) Schott)] no 
ensaio de letalidade com Artemia salina Leach, no teste antifúngico de microdiluição em caldo e na hipercolesterolemia em coelhos. Dissertação (Mestrado). Universidade Federal de Ouro Preto. Escola de Farmácia. Programa de Pós-graduação em Ciências Farmacêuticas. Ouro Preto, MG, 2011.

RIBEIRO, D.A.; MACÊDO, D.G.; OLIVEIRA, L.G.S.; SARAIVA, M.E.; OLIVEIRA, S.F.; SOUZA, M.M.A.; MENEZES, I.R.A. Potencial terapêutico e uso de plantas medicinais em uma área de Caatinga no estado do Ceará, nordeste do Brasil. Rev. Bras. PI. Med., Campinas, v.16, n.4, p.912-930, 2014.

RIBEIRO, G.E. Triagem fitoquímica, atividade antimicrobiana, antioxidante e citotoxicidade de extratos hidroetanólicos de Euphorbia cotinifolia (Leiteiro vermelho). Dissertação (Mestrado em Biociências Aplicadas à Saúde). Universidade Federal de Alfenas, Alfenas, MG, 2014. $64 \mathrm{f}$.

ROCHA, B. Propagação e genotoxicidade de Alternanthera brasiliana (L.) Kuntze (Amaranthaceae). Dissertação (Mestrado). Universidade Federal de Santa Maria. Programa de Pós-graduação em Agrobiologia. Santa Maria, RS, 2013.

RODRIGUES, H.G.; MEIRELES, C.G.; LIMA, J.T.S.; TOLEDO, G.P.; CARDOSO, J.L.; GOMES, S.L. Efeito embriotóxico, teratogênico e abortivo de plantas medicinais. Rev. Bras. PI. Med., Botucatu, v.13, n.3, p.359-366, 2011.

ROSA, R.L.; BARCELOS, A.L.V.; BAMPI, G. Investigação do uso de plantas medicinais no tratamento de indivíduos com diabetes melito na cidade de Herval D' Oeste - SC. Rev. Bras. PI. Med., Botucatu, v.14, n.2, p.306-310, 2012.

ROVANI, G.T.; SANTOS, V.L.P.; MIGUEL, O.G.; BUDEL, J.M.; CAMPOS, R. Investigação Fitoquímica e antioxidante de partes vegetativas aéreas de Piper amalago L. Cadernos da Escola de Saúde, Curitiba, v 2: 164-177, 2013.

SÁ, R.D.; SANTANA, A.S.C.O.; SILVA, F.C.L.; SOARES, L.A.L.; RANDAU, K.P. Anatomical and histochemical analysis of Dysphania ambrosioides supported by light and electron microscopy. Rev. bras. farmacogn., Curitiba, v.26, n.5, p.533-543, oct. 2016. 
SANTOS-OLIVEIRA, R.; COULAUD-CUNHA, S.; COLAÇO, W. Revisão da Maytenus ilicifolia Mart. ex Reissek, Celastraceae. Contribuição ao estudo das propriedades farmacológicas. Rev. Bras. Farmacogn. 19(2B): abr./jun. 2009.

SANTOS, F.M.; PINTO, J.E.B.P.; BERTOLUCCI, S.K.V.; ALVARENGA, A.A.; ALVES, M.N.; DUARTE, M.C.T.; SARTORATTO, A. Chemical composition and antimicrobial activity of the essential oil from the leaves and flowers of Aloysia gratissima. Rev. Bras. PI. Med., Campinas, v.15, n.4, p.583-588, 2013.

SCHAPOVAL, E.E.S.; VARGAS, M.R.W.; CHAVES, C.G.; BRIDI, R.; ZUANAZZI, J.A.; HENRIQUES, A.T. Antiinflammatory and antinociceptive activities of extracts and isolated compounds from Stachytarpheta cayennensis. J Ethnopharmacol. 1998 Feb;60(1):53-9.

SCHILLING, A.C.; BATISTA, J.L.F. Curva de acumulação de espécies e suficiência amostral em florestas tropicais. Revista brasil. Bot., v.31, n.1, p.179-187, jan.-mar. 2008.

SILVA, J.; ABEBE, W.; SOUSA, S.M.; DUARTE, V.G.; MACHADO, M.I.L.; MATOS, F.J.A. Analgesic and anti-inflammatory effects of essential oils of Eucalyptus. J Ethnopharmacol. 2003 Dec; 89(2-3):277-83.

SILVA, D.; MAGALHÃES, V.; MACEDO, T.; ALMASSY JR, A.; SILVA, F. Levantamento Etnofarmacológico em Comunidades Rurais do Recôncavo da Bahia/BA. Rev. Bras. De Agroecologia, v.4, n.2, nov. 2009.

SILVA, M.A.; BARBOSA, J.S.; ALBUQUERQUE, H.N. Levantamento das plantas espontâneas e suas potencialidades fitoterapêuticas: um estudo no complexo Aluízio Campos - Campina Grande - PB. Revista Brasileira de Informações Científicas, v.1, n.1, abr./jun. 2010.

SILVA, L.E.; QUADROS, D.A.; NETO, A.J.M. Estudo etnobotânico e etnofarmacológico de plantas medicinais utilizadas na região de Matinhos - PR. Ciência e Natura, v.37, n.2, p.266-276, mai./ago. 2015.

SILVEIRA, P. F.; BANDEIRA, M.A.M.; ARRAIS, P.S.D. Farmacovigilância e reações adversas às plantas medicinais e fitoterápicos: uma realidade. Revista Brasileira de Farmacognosia, 
18(4): 618-626, out./dez. 2008.

SOARES, A.K.A.; CARMO, G.C.; QUENTAL, D.P.; NASCIMENTO, D.F.; BEZERRA, F.A.F.; MORAES, M.O.; MORAES, M.E.A. Avaliação da segurança clínica de um fitoterápico contendo Mikania glomerata, Grindelia robusta, Copaifera officinalis, Myroxylon toluifera, Nasturtium officinale, própolis e mel em voluntários saudáveis. Rev. Bras. Farmacogn. 16(4): 447-454, out/dez. 2006.

SOSA, S.; BALICK, M.J.; ARVIGO, R.; ESPOSITO, R.G.; PIZZA, C.; ALTINIER, G.; TUBARO, A. Screening of the topical anti-inflammatory activity of some Central American plants. J Ethnopharmacol. 2002 Jul;81(2):211-215.

SOUSA, E.O.; BARRETO, F.S.; RODRIGUES, F.F.G.; COSTA, J.G.M. Atividade antibacteriana e interferência de Lantana camara L. e Lantana montevidensis (Spreng.) Briq. na resistência de aminoglicosídeos. R. bras. Bioci., Porto Alegre, v.9, n.1, p.1-5, jan./mar. 2011.

SOUZA, G.C.; HAAS, A.P.S.; POSER, G.L.; SCHAPOVAL, E.E.S.; ELISABETSKY, E. Ethnopharmacological studies of antimicrobial remedies in the south of Brazil. Journal of Ethnopharmacology 90 (2004) 135-143.

SOUZA, A.D.Z.; VARGAS, N.R.C.; CEOLIN, T.; HECK, R.M.; HAEFFNER, R.; VIEGAS, C.R.S. A enfermagem diante da utilização de plantas medicinais no tratamento complementar da hipertensão arterial sistêmica e das dislipidemias. REME - Rev. Min. Enferm.; 14(4): 473-478, out./dez., 2010.

SOUZA-MOREIRA, T.M.; MOREIRA, R.R.D.; SACRAMENTO, L.V.S.; PIETRO, R.C.L.R. Histochemical, phytochemical and biological screening of Plinia cauliflora (DC.) Kausel, Myrtaceae, leaves. Rev. bras. Farmacogn., Curitiba, v.20, n.1, p.48-53, mar. 2010.

STEFANELLO, M.E.A.; SALVADOR, M.J.; ITO, I.Y.; MACARI, P.A.T. Avaliação da atividade antimicrobiana e citotóxica de extratos de Gochnatia polymorpha ssp floccosa. Rev. Bras. Farmacogn. 16(4): out/dez. 2006.

STRAPASSON, R.L.B. Constituintes químicos e avaliação das atividades citotóxica e 
antioxidante de Moquiniastrum polymorphum subsp. floccosum (Asteraceae). Tese. Curitiba, Paraná: Universidade Federal do Paraná. 2014.

TIGNO, X.T.; GUZMAN, F; FLORA, A.M. Phytochemical analysis and hemodynamic actions of Artemisia vulgaris L. Clin Hemorheol Microcirc. 2000;23 (2-4): 167-75.

TOMAZZONI, M. I.; NEGRELLE, R. R. B.; CENTA, M. D. L. Fitoterapia popular: a busca instrumental enquanto prática terapêutica. Texto \& Contexto - Enfermagem, v. 15, p. 115121, 2006.

TRACZ, V.; CRUZ-SILVA, C.T.A.; LUZ, M. Z. Produção de mudas de penicilina (Alternanthera brasiliana (L.) Kuntze) via estaquia. Rev. Bras. PI. Med., Campinas, v.16, n.3, supl. I, p.644-648, 2014.

TRUITI, M.C.T.; SARRAGIOTTO, M.H.; ABREU FILHO, B.A.; NAKAMURA, C.V.; DIAS FILHO, B.P. In Vitro Antibacterial Activity of a 7-O- $\beta$-D-glucopyranosylnutanocoumarin from Chaptalia nutans (Asteraceae). Mem Inst Oswaldo Cruz, Rio de Janeiro, v.98(2), March 2003.

VASCONCELLOS, C.; HECK, R.; CEOLIN, T.; BARBIERI, R.; BORGES, A.; MUNIZ, L.; COSTA, N. Plantas medicinales utilizadas em mujeres em Brasil. 2011, Horiz Enferm, 22, 1, 23-33.

VEIGA JUNIOR, V. F.; PINTO, A. C.; MACIEL, M. A. M. Plantas medicinais: cura segura? Quím. Nova, v. 28, n. 3, p. 519-528, 2005.

VENDRUSCOLO, G.S.; RATES, S.M.K.; MENTZ, L.A. Dados químicos e farmacológicos sobre as plantas utilizadas como medicinais pela comunidade do bairro Ponta Grossa, Porto Alegre, Rio Grande do Sul. Revista Brasileira de Farmacognosia, 15(4): 361-372, out./dez. 2005.

VRCHOVSKÁ, V.; SOUSA, C.; VALENTÃO, P.; FERRERES, F.; PEREIRA, J.A.; SEABRA, R.M.; ANDRADE, P.B. Antioxidative properties of tronchuda cabbage (Brassica oleracea L. var. costata $\mathrm{DC}$ ) external leaves against $\mathrm{DPPH}$, superoxide radical, hydroxyl radical and hypochlorous acid. Food Chemistry 98 (2006) 416-425. 
WERKMAN, C.; GRANATO, D.C.; KERBAUY, W.D.; SAMPAIO, F.C.; BRANDÃO, A.A.H.; RODE, S.M. Aplicações terapêuticas da Punica granatum L. (romã). Rev. Bras. PI. Med., Botucatu, v.10, n.3, p.104-111, 2008.

WILLIAMSON, E.; DRIVER, S.; BAXTER, K. Interações medicamentosas de Stockley: plantas medicinais e medicamentos fitoterápicos. Porto Alegre: Artmed, 2012. 440 p.

ZANIN, S. M. W.; MIGUEL, M. D.; BARREIRA, S. M. W.; NAKASHIMA, T.; CURY, C. D.; COSTA, C. K. Enxaguatório bucal: principais ativos e desenvolvimento de fórmula contendo extrato hidroalcoólico de Salvia officinalis L. Visão Acadêmica, Curitiba, v.8, n.1, jan./jun. 2007.

ZHANG, Y.; SUN, Y.; XI, W.; SHEN, Y., QIAO, L.; ZHONG, L.; YE, X.; ZHOU, Z. Phenolic compositions and antioxidant capacities of Chinese wild mandarin (Citrus reticulata Blanco) fruits. Food Chem. 2014 Feb 15; 145: 674-80. 